Notre Dame Law Review

Volume 91 | Issue 3

Article 3

$4-2016$

\title{
The Supreme Court's Quiet Revolution in Induced Patent Infringement
}

Timothy R. Holbrook

Emory University School of Law

Follow this and additional works at: http://scholarship.law.nd.edu/ndlr

Part of the Intellectual Property Law Commons, and the Supreme Court of the United States Commons

\section{Recommended Citation}

91 Notre Dame L. Rev. 1007 (2016)

This Article is brought to you for free and open access by the Notre Dame Law Review at NDLScholarship. It has been accepted for inclusion in Notre Dame Law Review by an authorized administrator of NDLScholarship. For more information, please contact lawdr@nd.edu. 


\title{
THE SUPREME COURT'S QUIET REVOLUTION IN INDUCED PATENT INFRINGEMENT
}

\author{
Timothy R. Holbrook*
}

\begin{abstract}
The Supreme Court over the last decade or so has reengaged with patent law. While much attention has been paid to the Court's reworking of what constitutes patent-eligible subject matter and enhancing tools to combat "patent trolls," what many have missed is the Court's reworking of the contours of active inducement of patent infringement under 35 U.S.C. $\$ 271(b)$. The Court has taken the same number of $\$ 271(b)$ cases as subject matter eligibility cases-four. Yet this reworking has not garnered much attention in the literature. This Article offers the first comprehensive assessment of the Court's efforts to define active inducement. In so doing, it identifies the surprising significance of the Court's most recent case, Commil USA, LLC v. Cisco Systems, Inc., where the Court held that a good faith belief on the part of the accused inducer that the relevant patent is invalid cannot negate the mental state required for inducement-the intent to induce acts of infringement. In so doing, the Court moved away from its policy of encouraging challenges to patent validity as articulated in Lear, Inc. v. Adkins and its progeny. This step away from Lear is significant and surprising, particularly where critiques of the patent system suggest there are too many invalid patents creating issues for competition. This Article critiques these aspects of Commil and then addresses lingering, unanswered questions. In particular, this Article suggests that a good faith belief that the induced acts are not infringing, which remains as a defense, should only act as a shield against past damages and not against prospective relief such as injunctions or ongoing royalties. The courts so far have failed to appreciate this important temporal dynamic.
\end{abstract}

\section{INTRODUCTION}

The Supreme Court has taken a considerable, if not somewhat odd, interest in patent law over the last few years. ${ }^{1}$ Of all of the Court's interven-

(C) 2016 Timothy R. Holbrook. Individuals and nonprofit institutions may reproduce and distribute copies of this Article in any format at or below cost, for educational purposes, so long as each copy identifies the author, provides a citation to the Notre Dame Law Review, and includes this provision in the copyright notice.

* Professor of Law, Emory University School of Law. My thanks to Jason Rantanen and Keith Robinson for comments on a draft of this paper. Mistakes are my own.

1 See generally Timothy R. Holbrook, Explaining the Supreme Court's Interest in Patent Law, 3 IP Theory 62 (2013). Since that article was published, the Supreme Court took six cases its 2013 term, three in its 2014 term, and three cases in its 2015 term. See Cuozzo Speed Techs., LLC v. Lee, 136 S. Ct. 890 (2016) (granting certiorari); Halo Elecs., Inc. v. Pulse Elecs., Inc., 136 S. Ct. 356 (2015) (granting certiorari); Stryker Corp. v. Zimmer, Inc., 136 S. Ct. 356 (2015) (granting certiorari). For a summary of the issues in these cases, see 
tions, its substantial reworking of the law surrounding patentable subject matter under 35 U.S.C. $\S 101^{2}$ has garnered most attention and commentary. ${ }^{3}$

Many have missed, however, the quiet revolution the Court has instigated with respect to active inducement of patent infringement under 35 U.S.C. $\$ 271(\mathrm{~b})$. The provision somewhat tersely states, "Whoever actively induces infringement of a patent shall be liable as an infringer." 4 Given this general, unenlightening language, the courts have been left to determine the contours of this provision, and the Supreme Court has been paying attention. Since the October 2004 term, the Supreme Court has decided four cases interpreting that provision, ${ }^{5}$ the same number of cases as the Court's

Supreme Court Patent Cases, WRITTEN DEsCRIPTION, http:/ /writtendescription.blogspot.com/ p/patents-scotus.html (last visited Mar. 25, 2016).

2 See, e.g., Alice Corp. v. CLS Bank Int'l, 134 S. Ct. 2347 (2014); Ass'n for Molecular Pathology v. Myriad Genetics, Inc., 133 S. Ct. 2107 (2013); Mayo Collaborative Servs. v. Prometheus Labs., Inc., 132 S. Ct. 1289 (2012); Bilski v. Kappos, 561 U.S. 593 (2010).

3 See, e.g., J. Jonas Anderson, Applying Patent-Eligible Subject Matter Restrictions, 17 VAND. J. Ent. \& Tech. L. 267 (2015); Tun-Jen Chiang, Competing Visions of Patentable Subject Matter, 82 Geo. Wash. L. Rev. 1858 (2014); Kevin Emerson Collins, The Knowledge/Embodiment Dichotomy, 47 U.C. Davis L. Rev. 1279 (2014); Timothy R. Holbrook \& Mark D. Janis, Patent-Eligible Processes: An Audience Perspective, 17 Vand. J. Ent. \& TEch. L. 349 (2015); Christopher M. Holman, Patent Eligibility Post-Myriad: A Reinvigorated Judicial Wildcard of Uncertain Effect, 82 Geo. Wash. L. Rev. 1796 (2014); Mark A. Lemley et al., Life After Bilski, 63 Stan. L. Rev. 1315 (2011); Jacob S. Sherkow, The Natural Complexity of Patent Eligibility, 99 IowA L. REV. 1137 (2014).

435 U.S.C. $\$ 271$ (b) (2012).

5 Commil USA, LLC v. Cisco Sys., Inc., 135 S. Ct. 1920 (2015); Limelight Networks, Inc. v. Akamai Techs., Inc., 134 S. Ct. 2111 (2014); Glob.-Tech Appliances, Inc., v. SEB S.A., 131 S. Ct. 2060 (2011); Metro-Goldwyn-Mayer Studios Inc. v. Grokster, Ltd., 545 U.S. 913 (2005). While Grokster is technically a copyright case, the Supreme Court imported active inducement of infringement from patent law into copyright law. See Grokster, 545 U.S. at 936-37. The Court said:

For the same reasons that Sony took the staple-article doctrine of patent law as a model for its copyright safe-harbor rule, the inducement rule, too, is a sensible one for copyright. We adopt it here, holding that one who distributes a device with the object of promoting its use to infringe copyright, as shown by clear expression or other affirmative steps taken to foster infringement, is liable for the resulting acts of infringement by third parties.

Id. (citing Sony Corp. of Am. v. Universal City Studios, Inc., 464 U.S. 417 (1984)). Grokster has been influential in the development of induced infringement in patent law as a result. See, e.g., Takeda Pharms. U.S.A., Inc. v. West-Ward Pharm. Corp., 785 F.3d 625, 630-31 (Fed. Cir. 2015) (discussing Grokster in interpreting \$ 271(b)); DSU Med. Corp. v. JMS Co., 471 F.3d 1293, 1305-06 (Fed. Cir. 2006) (en banc in relevant part) (using Grokster to clarify intent standard under $\$ 271(\mathrm{~b})$ ); see also Timothy R. Holbrook, The Intent Element of Induced Infringement, 22 Santa Clara Computer \& High Tech. L.J. 399, 400-04, 407-08 (2006) [hereinafter Holbrook, Intent Element] (discussing Grokster and implications for patent law).

The Court also addressed 35 U.S.C. $\$ 271(\mathrm{f})$ in Microsoft Corp. v. ATẼT Corp., 550 U.S. 437 (2007), which contains a provision regarding the inducement of infringement outside of the United States. See generally Timothy R. Holbrook, Extraterritoriality in U.S. Patent Law, 49 WM. \& Mary L. Rev. 2119, 2132-36 (2008) (discussing \$271(f) and its extraterritorial 
subject matter eligibility cases. ${ }^{6}$ In the October 2015 term, the Court issued its most recent interpretation of $\S 271$ (b) in Commil USA, LLC v. Cisco Systems, Inc., holding that an accused infringer's good faith belief that the relevant patent is invalid does not negate the requisite intent for inducing infringement. ${ }^{7}$

These cases provide important and interesting insights into the Supreme Court's views of patent law. At a minimum, the Court's active inducement decisions have favored the patent owner for the most part, which contrasts sharply with the general anti-patentee trend in the Court's other patent cases. $^{8}$ These four decisions, and particularly Commil, signal significant changes in the Supreme Court's views of patent law and policy. By holding that a good faith belief that the relevant patent is invalid does not negate the

reach). Thus, one could say the Supreme Court has actually addressed induced infringement five times since 2007.

Additionally, the Federal Circuit recently decided Suprema, Inc. v. International Trade Commission, 796 F.3d 1338, 1340-41 (Fed. Cir. 2015) (en banc), expanding the ability of patent owners to use inducement theories at the International Trade Commission (ITC). The en banc court reversed the holding of the panel in the case, which concluded that the ITC could not exclude articles that, only subsequent to importation, could be arranged to infringe the patented methods. See Suprema, Inc. v. Int'l Trade Comm'n, 742 F.3d 1350, 1357 (Fed. Cir. 2013), vacated 796 F.3d 1338 (Fed. Cir. 2015) (en banc). On a 6-5 vote, the en banc court permitted such claims. Suprema, 796 F.3d at 1340-41. The split decision by the en banc court may garner the attention of the Supreme Court, assuming a petition for a writ of certiorari is filed. See John F. Duffy, The Festo Decision and the Return of the Supreme Court to the Bar of Patents, 2002 Sup. Ст. Rev. 273, 284 ("The extended treatment by the Federal Circuit signaled to the Supreme Court the importance of the issue and provided a rich discussion of the competing interests at stake that increased the Justices' ability to comprehend and review the case."); Holbrook, supra note 1, at 69-70 (noting split en banc decisions as a factor favoring Supreme Court review).

6 See supra note 5.

7 Commil, 135 S. Ct. at 1931.

8 Other pro-patent rulings include Bowman v. Monsanto Co., 133 S. Ct. 1761, 1766-69 (2013) (finding patent not exhausted, and thus infringed, by replication of patented seeds), Microsoft Corp. v. i4i Ltd. Partnership, 131 S. Ct. 2238, 2242 (2011) (holding patent invalidity must be proven by "clear and convincing evidence"), and Festo Corp. v. Shoketsu Kinzoku Kogyo Kabushiki Co., 535 U.S. 722, 737-41 (2002) (rejecting the Federal Circuit's bright-line "complete surrender" rule for prosecution history estoppel, making it easier to avoid estoppel and prove infringement under the doctrine of equivalents). Many of the Court's decisions, however, have been viewed as weakening the power of patents. See, e.g., Nautilus, Inc. v. Biosig Instruments, Inc., 134 S. Ct. 2120, 2124, 2128-31 (2014) (making it easier to prove patent claims are invalid as indefinite); KSR Int'l Co. v. Teleflex Inc., 550 U.S. 398 (2007) (rejecting formalistic "teaching-suggestion-motivation to combine" test for more flexible rule, making it easier to prove patents are invalid as obvious); eBay Inc. v. MercExchange, L.L.C., 547 U.S. 388, 391-94 (2006) (eliminating rule for near per se grant of permanent injunctions in patent cases). The Supreme Court's decisions regarding what subject matter is eligible to be patented have greatly curtailed patent protection for many innovations. See Alice Corp. v. CLS Bank Int'l, 134 S. Ct. 2347 (2014); Ass'n for Molecular Pathology v. Myriad Genetics, Inc., 133 S. Ct. 2107 (2013); Mayo Collaborative Servs. v. Prometheus Labs., Inc., 132 S. Ct. 1289 (2012); Bilski v. Kappos. 561 U.S. 593 (2010) (all invalidating claims as lacking patentable subject matter). 
scienter requirement for active inducement, Commil represents a step away from the Court's policy preference of encouraging patent validity challenges in courts, as previously articulated in Lear, Inc. v. Adkins ${ }^{9}$ and its progeny.

This Article is the first to provide a comprehensive assessment of this quiet revolution. It unpacks these important developments, particularly highlighting the implications of Commil. It then explores some unanswered questions in Commil. It highlights a glaring oversight not only in the Commil decision but also with all of the jurisprudence under $\$ 271(\mathrm{~b})$ - the failure of the courts to recognize that a good faith belief (now only of non-infringement) should only shelter an accused infringer from past damages; the infringer should be subject to prospective remedies, such as ongoing royalties and permanent injunctions. Part I offers an overview of the tetralogy of cases and their broader impact. Part II then elaborates how the Court's decision in Global-Tech Appliances, Inc. v. SEB S.A. ${ }^{10}$ advanced the Lear policy interest by encouraging potential infringers to review patents or else face liability. If such a review revealed a belief that the relevant patent was invalid, the parties would be more likely and willing to enter the market and ultimately challenge the patent. Commil, however, has greatly undermined this dynamic by eliminating a good faith belief that the patent is invalid as a defense to active inducement. Part III then discusses two open questions after Commil. First, it evaluates whether Commil eliminates other good faith defenses from active inducement, concluding that it does. Second, and more importantly, Part III argues that the remaining good faith defense-that the patent is invalid-should only preclude past damages and not prospective relief.

\section{The Inducement Tetralogy-Grokster, Global-Tech, LIMELIGHT, AND COMMIL}

Prior to the adoption of the 1952 Patent Act, case law made clear that third parties could be held liable for the infringing acts of others through theories of joint tortfeasance. ${ }^{11}$ When Congress adopted the 1952 Patent Act, it codified this common law into two forms of indirect infringement: active inducement under 35 U.S.C. $\$ 271$ (b) and contributory infringement under 35 U.S.C. $\$ 271$ (c), ${ }^{12}$ the latter of which was the "most common" pre1952 scenario for such indirect liability - the sale of a component of a patentee invention that is then incorporated into an infringing item. ${ }^{13}$

9 See Lear, Inc. v. Adkins, 395 U.S. 653 (1969). Commentators have been critical of Lear. See, e.g., Rochelle Cooper Dreyfuss, Dethroning Lear: Licensee Estoppel and the Incentive to Innovate, 72 VA. L. REv. 677, 683 (1986) (summarizing critique).

10131 S. Ct. 2060 (2011).

11 Hewlett-Packard Co. v. Bausch \& Lomb Inc., 909 F.2d 1464, 1468-69 (Fed. Cir. 1990) ("Prior to the enactment of the Patent Act of 1952, there was no statute which defined what constituted infringement.").

$12 I d$. at 1469.

13 Id. 
Although Congress included within $§ 271$ (c) considerable details as to its requirements, ${ }^{14} \S 271$ (b) remains a vague, catch-all provision, the contours of which were left to the courts to determine. ${ }^{15}$ Notwithstanding this apparent delegation to the courts, the Supreme Court remained silent with respect to active inducement until the mid-2000s. While the Court did address $\S 271$ (c) in 1964 in Aro Manufacturing Co. v. Convertible Top Replacement Co. ${ }^{16}$ it took the Court over fifty years ${ }^{17}$ to address $§ 271(\mathrm{~b})$. Somewhat surprisingly, when it decided to do so, it was in a copyright case.

\section{A. Induced Infringement and Illegal Downloads of Copyrighted Works in MGM Studios, Inc. v. Grokster, Ltd.}

The Supreme Court's first substantive discussion of $\S 271(\mathrm{~b})$ arose in the context of illegal digital downloads of copyrighted music. The accused copyright infringers, Grokster and StreamCast, ran a peer-to-peer file sharing systems whose primary uses were to exchange copyrighted music among users without permission from the copyright holders. ${ }^{18}$ Prior to the decision, most observers believed that the Court would elaborate on its decision in Sony Corp. of America v. Universal City Studios, Inc. and explain its application in the online context. ${ }^{19}$ In Sony, the Supreme Court incorporated patent law's contributory infringement doctrine under $\S 271(\mathrm{c})$ into copyright law. ${ }^{20}$ That provision creates a safe harbor from liability if the component sold or imported has a substantial use that does not result in infringement of the

14 Section 271(c) defines contributory infringement as:

Whoever offers to sell or sells within the United States or imports into the United States a component of a patented machine, manufacture, combination or composition, or a material or apparatus for use in practicing a patented process, constituting a material part of the invention, knowing the same to be especially made or especially adapted for use in an infringement of such patent, and not a staple article or commodity of commerce suitable for substantial noninfringing use, shall be liable as a contributory infringer.

35 U.S.C. $\$ 271$ (c) (2012). It reduces to three basic requirements: (1) a sale, offer to sell, or importation of (2) a component of the patented invention with (3) no substantial noninfringing uses. The Supreme Court also clarified in Aro Manufacturing Co. v. Convertible Top Replacement Co., 377 U.S. 476, 488 (1964), that liability for contributory infringement requires the contributory infringer to know that the combination was both patented and infringed, creating a fourth, knowledge requirement.

15 See Lynda J. Oswald, The Intent Element of "Inducement to Infringe" Under Patent Law: Reflections on Grokster, 13 Мich. Telecomm. \& Tech. L. Rev. 225, 229-31 (2006) (discussing the evolution of $\$ 271$ (b) doctrine).

16377 U.S. 476 (1964).

17 The Supreme Court addressed 35 U.S.C. \$ 271(d) in Dawson Chemical Co. v. Rohm E Haas Co., 448 U.S. 176 (1980), a provision that places limits on a patent misuse defense, which often arises in the context of contributory infringement. But the Court did not address the substance of either $\$ 271$ (b) or $\$ 271$ (c).

18 Metro-Goldwyn-Mayer Studios Inc. v. Grokster, Ltd., 545 U.S. 913, 919-20 (2005).

19464 U.S. 417 (1984).

$20 I d$. at $439-42$. 
patent. ${ }^{21}$ Drawing on the idea of substantial non-infringing uses, the Supreme Court in Sony concluded that the manufacturers of VCRs were not liable for contributory copyright infringement because VCRs had such a noninfringing use: allowing people to tape shows to watch at a later time. ${ }^{22}$

Many thought that Grokster would address the same issue-whether filesharing networks had substantial non-infringing uses, such as sharing files that were not subject to copyright or for which the copyright owner had granted permission. ${ }^{23}$ Those expectations were not realized. The Supreme Court in Grokster dodged the "substantial non-infringing uses" question ${ }^{24}$ and instead imported active inducement of infringement into copyright law from patent law. ${ }^{25}$ The Court held that "one who distributes a device with the object of promoting its use to infringe copyright, as shown by clear expression or other affirmative steps taken to foster infringement, is liable for the resulting acts of infringement by third parties." 26

In embracing active inducement of infringement for copyright law, the Supreme Court discussed the requisite mental state for an inducer. The Court noted that inducement "premises liability on purposeful, culpable expression and conduct." 27 In the Court's view, Groskter and StreamCast possessed the required, nefarious intent: "Grokster and StreamCast's efforts to supply services to former Napster users, deprived of a mechanism to copy and distribute what were overwhelmingly infringing files, indicate a principal, if not exclusive, intent on the part of each to bring about infringement." 28 Ultimately, the Court concluded that " $[t]$ he unlawful objective is unmistakable." 29

Although Grokster was a copyright case, it quickly proved to be influential in patent law. The Federal Circuit relied upon Grokster to resolve a split in its

2135 U.S.C. $\$ 271$ (c); see also Sony, 464 U.S. at 441 ("These cases deny the patentee any right to control the distribution of unpatented articles unless they are "unsuited for any commercial noninfringing use." (quoting Dawson Chemical Co., 448 U.S. at 198)).

22 Sony, 464 U.S. at 456. The Court concluded time-shifting was non-infringing because it constitutes fair use. Id. at 454-55.

23 See Holbrook, Intent Element, supra note 5, at 399.

24 Metro-Goldwyn-Mayer Studios Inc. v. Grokster, Ltd., 545 U.S. 913, 934 (2005) ("[W]e do not revisit Sony further, as MGM requests, to add a more quantified description of the point of balance between protection and commerce when liability rests solely on distribution with knowledge that unlawful use will occur.”). Justice Ginsburg, concurring, did offer an elaboration on Sony with respect to the facts of this case, see id. at 942-49 (Ginsburg, J., concurring), generating a disagreement with Justice Breyer, see id. at 949 (Breyer, J., concurring) ("Other Members of the Court, however, take up the Sony question . . . I I write to explain why I disagree with them on this matter.”). This splinter may explain why the Court chose the inducement route.

$25 I d$. at 936 (majority opinion) ("For the same reasons that Sony took the staple-article doctrine of patent law as a model for its copyright safe-harbor rule, the inducement rule, too, is a sensible one for copyright.").

26 Id. at 936-37.

27 Id. at 937.

28 Id. at 939.

29 Id. at 940. 
case law regarding the required mental state for a party to be liable for inducing infringement. ${ }^{30}$ Federal Circuit decisions had articulated two inconsistent standards for required intent. The first standard required the inducer to have the intent to induce the acts that constitute direct infringement. ${ }^{31}$ Under this broad test, an inducer need not know that the induced acts actually did constitute infringement to be liable. The other standard required an intent to induce infringement. ${ }^{32}$ This narrower standard required the inducer to know that the induced acts would constitute infringement, which also would require knowledge of the patent. ${ }^{33}$

Prior to Grokster, the Federal Circuit had avoided resolving the internal split a number of times. ${ }^{34}$ After Grokster, the court finally held en banc that the latter, narrower standard was correct. ${ }^{35}$ In reaching this conclusion, the Federal Circuit relied upon the language in Grokster discussing the mental states of Grokster and StreamCast. The court noted that "Grokster, thus, validates this court's articulation of the state of mind requirement for inducement." 36 Specifically, the Federal Circuit reasoned that "Grokster has clarified that the intent requirement for inducement requires more than just intent to cause the acts that produce direct infringement. Beyond that threshold knowledge, the inducer must have an affirmative intent to cause direct

30 See Mark A. Lemley, Inducing Patent Infringement, 39 U.C. DAvis L. Rev. 225, 240 (2005) ("This division in authority has continued to plague the courts. Federal Circuit and district court opinions have variously followed both standards, though they lean heavily toward the Manville approach. The Federal Circuit has tried without success to reconcile the standards." (footnote omitted)); Oswald, supra note 15, at 231 ("The Federal Circuit has acknowledged a sharp intra-circuit split in its jurisprudence relating to the type of intent required to support an inducement of infringement action under section 271(b) of the Patent Act.”); Michael N. Rader, Toward a Coherent Law of Inducement to Infringe: Why the Federal Circuit Should Adopt the Hewlett-Packard Standard for Intent Under $\$ 271(b), 10$ FED. Cir. B.J. 299, 300 (2000) ("By issuing conflicting decisions on the matter, the Federal Circuit has created a great deal of uncertainty in district courts as to the controlling standard.").

31 Hewlett-Packard Co. v. Bausch \& Lomb Inc., 909 F.2d 1464, 1469 (Fed. Cir. 1990).

32 Manville Sales Corp. v. Paramount Sys., Inc., 917 F.2d 544, 553 (Fed. Cir. 1990).

33 Cf. Lemley, supra note 30, at 238 ("The Hewlett-Packard court did not require that the defendant have any awareness of the patent, much less intend to infringe it . . ..").

34 MEMC Elec. Materials, Inc. v. Mitsubishi Materials Silicon Corp., 420 F.3d 1369, 1378 n.4 (Fed. Cir. 2005); MercExchange, L.L.C. v. eBay, Inc., 401 F.3d 1323, 1332 (Fed. Cir. 2005), vacated and remanded, eBay, Inc. v. MercExchange, L.L.C., 547 U.S. 388 (2006) (" $[\mathrm{T}]$ here is a 'lack of clarity concerning whether the required intent must be merely to induce the specific acts [of infringement] or additionally to cause an infringement.", (quoting Insituform Techs., Inc. v. CAT Contracting, Inc., 385 F.3d 1360, 1378 (Fed. Cir. 2004))); Insituform Techs., 385 F.3d at 1378 (“[W] e need not resolve any ambiguity in the case law on this point because there is sufficient evidence to support the district court's finding under either standard.”); see also Lemley, supra note 30, at 240.

35 DSU Medical Corp. v. JMS Co., 471 F.3d 1293, 1304-06 (Fed. Cir. 2006) (en banc in relevant part).

$36 \quad$ Id. at 1306. 
infringement." 37 Thus, in the eyes of the Federal Circuit, Grokster resolved the court's intra-circuit split on the mental state issue.

\section{B. The Supreme Court Revisits Induced Infringement in Global-Tech Appliances, Inc. v. SEB S.A.}

The certainty about the mental state requirement was short-lived, however. $^{38}$ In SEB S.A. v. Montgomery Ward $\mathcal{E}$ Co., the Federal Circuit addressed whether a party could possess the required knowledge of the patent under $D S U$ even if she was unaware of the actual patent at issue. ${ }^{39}$ The court concluded that deliberate indifference towards the risk there is a patent sufficed to demonstrate knowledge of the patent. ${ }^{40}$ Drawing on specific intent from other civil contexts, the court defined "deliberate indifference" as "a subjective determination that the defendant knew of and disregarded the overt risk that an element of the offense existed." ${ }^{1}$ Such indifference "is not different from actual knowledge, but is a form of actual knowledge." 42 In this way, the court appeared to broaden the knowledge and intent standard that it recently had narrowed in $D S U .^{43}$

The Supreme Court granted certiorari, however, and modified the standard. In Global-Tech Appliances, Inc. v. SEB S.A., the Court first addressed a threshold issue that it had never considered before: is there a knowledge requirement for $\S 271$ (b) at all? ${ }^{44}$ The Court concluded there is, though it was a close call. After concluding that the statutory language did not answer the question, the Court revisited its decision in Aro Manufacturing. Co. v. Convertible Top Replacement Co. (Aro II). In Aro II, the Court held, five to four, that there was a knowledge requirement for contributory infringement under $\S 271(\mathrm{c}) .{ }^{45}$ The Court in Global-Tech noted that

$37 \quad I d$.

38 Jason A. Rantanen, An Objective View of Fault in Patent Infringement, 60 Aм. U. L. REv. 1575 , 1579 (2011) ("Even after the Federal Circuit theoretically settled the mental state requirement of inducement once and for all in DSU Medical v.JMS, subsequent panels and scholars continued to disagree on its interpretation." (footnote omitted)).

39594 F.3d 1360, 1375-76 (Fed. Cir. 2010) (quoting 35 U.S.C. § 271(b) (2012)).

$40 \quad$ Id. at $1376-77$.

41 Id. at 1376 (citing Farmer v. Brennan, 511 U.S. 825, 840 (1994)).

$42 I d$. at 1377 (citing United States v. Carani, 492 F.3d 867, 873 (7th Cir. 2007); Woodman v. WWOR-TV, Inc., 411 F.3d 69, 84 n.14 (2d Cir. 2005)).

43 The court explicitly distinguished DSU:

The facts of DSU Medical did not require this court to address the scope of the knowledge requirement for intent. Instead, the court resolved conflicting case law setting forth both a requirement to knowingly induce infringement and to merely knowingly induce the acts that constitute direct infringement. In other words, the court decided the target of the knowledge, not the nature of that knowledge.

SEB, 594 F.3d at 1376 (citations omitted).

44131 S. Ct. 2060, 2068 (2011).

45377 U.S. 476,488 (1964). 
[w] hile there is much to be said in favor of both views expressed in Aro II, the "holding in Aro II has become a fixture in the law of contributory infringement under [section] 271(c),"-so much so that SEB has not asked us to overrule it. Nor has Congress seen fit to alter $\$ 271$ (c)'s intent requirement in the nearly half a century since Aro II was decided. In light of the "special force" of the doctrine of stare decisis with regard to questions of statutory interpretation, we proceed on the premise that $\S 271(\mathrm{c})$ requires knowledge of the existence of the patent that is infringed.

Based on this premise, it follows that the same knowledge is needed for induced infringement under $\S 271(\mathrm{~b}) .{ }^{46}$

Consequently, the Court held "that induced infringement under $§ 271$ (b) requires knowledge that the induced acts constitute patent infringement." 47

After concluding that inducement under $\$ 271(\mathrm{~b})$ requires knowledge of the patent, the Court then elaborated on what constitutes such knowledge. Rejecting the Federal Circuit's "deliberate indifference" test, the Court instead adopted criminal law's "willful blindness" standard for the knowledge requirement. ${ }^{48}$ Willful blindness requires that "(1) the defendant must subjectively believe that there is a high probability that a fact exists and (2) the defendant must take deliberate actions to avoid learning of that fact." ${ }^{9}$ The Federal Circuit's "deliberate indifference" was not the appropriate standard, according to the Court, because "it permits a finding of knowledge when there is merely a 'known risk' that the induced acts are infringing" and because it "does not require active efforts by an inducer to avoid knowing about the infringing nature of the activities." 50

The Supreme Court's decision in Global-Tech is a middle-of-the-road answer to the issue of knowledge. By adopting a knowledge requirement, the Court avoided making induced infringement a form of strict liability, which could ensnare truly innocent actors. By definition, the inducer's own activities are not infringing, yet they would be liable for the acts of others even if they were ignorant of the patent. With the knowledge requirement, parties are liable only if they are, in some sense, a bad actor.

The Court could have gone to the other extreme as well, requiring a party to have actual knowledge of the patent. Neither willful blindness nor deliberate indifference would suffice. This would be a far narrower approach, one which parties could game by "playing ostrich" to avoid liability, at least as to past damages. To avoid any liability for inducement, a party

46 Glob.-Tech, 131 S. Ct. at 2068 (alterations in original) (citations omitted) (quoting 5 R. Carl Moy, Moy’s Walker on Patents $§ 15: 20$, at 15-131 (4th ed. 2009)).

$47 I d$. For an argument that both Aro II and Glob.-Tech are wrong for requiring knowledge of patent infringement, see generally Ted Sichelman, Patent Law Revisionism at the Supreme Court?, 45 Loy. U. CHI. L.J. 307, 339 (2013).

48 Glob.-Tech, 131 S. Ct. at 2068 ("[D] eliberate indifference to a known risk that a patent exists is not the appropriate standard under $§ 271(\mathrm{~b})$. We nevertheless affirm the judgment of the Court of Appeals because the evidence in this case was plainly sufficient to support a finding of Pentalpha's knowledge under the doctrine of willful blindness.").

$49 I d$. at 2070.

$50 \quad I d$. at 2071. 
would simply refuse to review patents. The Court's "willful blindness" standard avoids this potential gamesmanship. But "willful blindness" is not as capacious as the Federal Circuit's "deliberate indifference" standard, striking a careful balance by ensuring that the actor affirmatively maintains her ignorance. Overall, the Court balanced the interest in preventing parties from burying their heads in the sand to avoid liability with a concern of ensnaring arguably innocent parties through $§ 271(b)$.

\section{The Supreme Court Responds to the Federal Circuit's Attempt to Redefine Induced Infringement: Limelight Networks, Inc. v.}

Akamai Technologies, Inc.

Although it took over fifty years for the Court to address $\$ 271$ (b) for the first time in the patent context, it took a mere three years for the Court to revisit the provision in Limelight Networks, Inc. v. Akamai Technologies, Inc. ${ }^{51}$ This time, however, the issue was not the mental state required for induced infringement. Instead, the Court rejected an attempt by the Federal Circuit to morph active inducement in a way to combat what has been dubbed "divided infringement." 52

Divided infringement arises when multiple parties perform the steps of a patented method, but no single party performs all of the steps. For example, the claim may require steps A, B, and C. Suppose that Attila performs steps A and $\mathrm{B}$, but Bubba then performs step $\mathrm{C} .{ }^{53}$ The patented process has been performed but not by a single entity. Under Federal Circuit law, to infringe a method claim, generally all of the steps must be performed by a single entity. ${ }^{54}$ Here, there would be no infringement because neither Attila nor Bubba performs all the steps of the claimed method.

The exception to the "single entity" rule is when activities of a third party are attributable to the accused infringer such that the accused infringer should be deemed responsible for performance of those steps. So, if there is a reason to attribute Bubba's performance of step $\mathrm{C}$ to Attila, then Attila would be liable as the direct infringer. Under Federal Circuit law, attribution is appropriate when the accused infringer exercises " control or direction" over the entire process such that every step is attributable to the controlling party, i.e., the "mastermind." 55 This "control or direction" test "is satisfied in situations where the law would traditionally hold the accused direct infringer vicariously liable for the acts committed by another party that are required to complete performance of a claimed method." 56

51134 S. Ct. 2111 (2014).

52 Mark A. Lemley et al., Divided Infringment Claims, 33 AIPLA Q.J. 255 (2005).

53 Attila and Bubba are my dogs.

54 See Muniauction, Inc. v. Thomson Corp., 532 F.3d 1318, 1328 (Fed. Cir. 2008); BMC

Res., Inc. v. Paymentech L.P., 498 F.3d 1373, 1378-79 (Fed. Cir. 2007).

55 Muniauction, 532 F.3d at 1329 (quoting BMC Res., 498 F.3d at 1381).

56 Id. at 1330 (citing BMC Res., 498 F.3d at 1379; Int'l Rectifier v. Samsung Elecs. Co., 361 F.3d 1355, 1361 (Fed. Cir. 2004)). 
The Federal Circuit sought to clarify the "control or direction" test in Akamai Technologies, Inc. v. Limelight Networks, Inc. ${ }^{57}$ In so doing, it dramatically altered the test. The court reasoned that

$[\mathrm{w}]$ hile control or direction is a consideration, as is the extent to which instructions, if any, may be provided, what is essential is not merely the exercise of control or the providing of instructions, but whether the relationship between the parties is such that acts of one may be attributed to the other. ${ }^{58}$

According to the court, attribution is appropriate in only two circumstances: "when there is an agency relationship between the parties who perform the method steps or when one party is contractually obligated to the other to perform the steps." 59

This narrowing of the "control or direction" test seemingly was to be short-lived because the Federal Circuit agreed to rehear the case en banc. ${ }^{60}$ The court appeared to want to revisit the single-entity rule. The question presented was: "If separate entities each perform separate steps of a method claim, under what circumstances would that claim be directly infringed and to what extent would each of the parties be liable?"61

The court also took a second case en banc, McKesson Technologies, Inc. $v$. Epic Systems Corporation ${ }^{62}$ that presented a slightly different issue of divided infringement. The defendant in Akamai performed some of the steps (and its customers performed the balance of the steps). In contrast, the defendant in McKesson performed none of the steps; instead the steps of the process were performed by two different actors: doctors and patients. ${ }^{63}$ The defendant's liability in McKesson, therefore, depended entirely on a theory of induced infringement under $\S 271(\mathrm{~b})$. The court posed the following questions in McKesson: "1. If separate entities each perform separate steps of a method claim, under what circumstances, if any, would either entity or any third party be liable for inducing infringement or for contributory infringement?" and "2. Does the nature of the relationship between the relevant actors-e.g., service provider/user; doctor/patient-affect the question of direct or indirect infringement liability?" 64 All of the questions presented

57629 F.3d 1311, 1319 (Fed. Cir. 2011), reh'g en banc granted, vacated, 419 F. App'x 989 (Fed. Cir. 2011) (en banc) (per curiam), rev'd and remanded, 692 F.3d 1301 (Fed. Cir. 2012) (en banc), rev'd and remanded, Limelight Networks, Inc. v. Akamai Techs., Inc., 134 S. Ct. 895 (2014), aff'd, 786 F.3d 899 (2015).

58 Akamai Techs., 629 F.3d at 1319.

59 Id. at 1320.

60 Akamai Techs., Inc. v. MIT, 419 F. App’x 989 (Fed. Cir. 2011) (en banc) (per curiam).

61 Id. at 989; see also Akamai Techs., Inc. v. Limelight Networks, Inc., 692 F.3d 1301, 1305 (Fed. Cir. 2012) (en banc) (per curiam).

62 McKesson Techs. Inc. v. Epic Sys. Corp., No. 2010-1291, 2011 U.S. App. LEXIS 7531, at*1 (U.S. Apr.18, 2014). Although the decision issued as a precedential one, it was never printed in the Federal Reporter given the grant of en banc review.

63 Id. at *7-11.

64 McKesson Techs. Inc. v. Epic Sys. Corp., 463 F. App’x 906, 907 (Fed. Cir. 2011) (en banc) (citation omitted). 
strongly suggested that the Federal Circuit was going to revisit the "single entity" rule for direct infringement of patented methods.

Any such expectations were dashed when the opinion was issued. Instead of addressing the direct infringement standard, the court left its prior law in place. In order to address the policy concerns of divided infringement, the court chose to rework the standard for inducing infringement under $\S 271$ (b). ${ }^{65}$ The court held that a party could be liable for active inducement of infringement even if no single party performed all the steps of the claimed method, so long as all of the steps were performed by someone. ${ }^{66}$ In the court's view, "[r] equiring proof that there has been direct infringement as a predicate for induced infringement is not the same as requiring proof that a single party would be liable as a direct infringer." 67 Thus, a party could be liable for active inducement of infringement if it performed some steps of the method and induced others to perform the remaining steps (per the Akamai fact scenario) ${ }^{68}$ or if a party induced multiple parties to perform all of the steps (per the McKesson scenario), ${ }^{69}$ even though there would be no individual who could be liable for direct infringement. ${ }^{70}$

The Supreme Court agreed to review the active inducement issue ${ }^{71}$ but declined to take up the direct infringement issue. ${ }^{72}$ Before the grant of certiorari, however, the McKesson case settled. ${ }^{73}$ McKesson was the one in which active inducement had been the issue all along, not Akamai. That left Akamai in an odd position: defending the Federal Circuit's holding on active inducement even though that issue was never present in its case prior to the Federal Circuit's en banc decision. Consequently and unsurprisingly, Akamai tried to

65 Akamai, 692 F.3d at 1306, rev'd, Limelight Networks Inc. v. Akamai Techs., Inc., 134 S. Ct. 2111 (2014) ("Much of the briefing in these cases has been directed to the question whether direct infringement can be found when no single entity performs all of the claimed steps of the patent. It is not necessary for us to resolve that issue today because we find that these cases and cases like them can be resolved through an application of the doctrine of induced infringement.").

$66 I d$. ("To be clear, we hold that all the steps of a claimed method must be performed in order to find induced infringement, but that it is not necessary to prove that all the steps were committed by a single entity.").

67 Id. at 1308-09 (emphasis omitted).

$68 I d$. at 1309 (“[A] party who performs some of the steps itself and induces another to perform the remaining steps that constitute infringement has precisely the same impact on the patentee as a party who induces a single person to carry out all of the steps.”).

$69 I d$. ("A party who knowingly induces others to engage in acts that collectively practice the steps of the patented method-and those others perform those acts-has had precisely the same impact on the patentee as a party who induces the same infringement by a single direct infringer; there is no reason, either in the text of the statute or in the policy underlying it, to treat the two inducers differently.").

70 For a discussion and critique of the Federal Circuit's decision, see W. Keith Robinson, No "Direction" Home: An Alternative Approach to Joint Infringement, 62 Aм. U. L. Rev. 59 (2012).

71 Limelight Networks, Inc. v. Akamai Techs., Inc., 134 S. Ct. 895 (2014).

72 Akamai Techs., Inc. v. Limelight Networks, Inc., 134 S. Ct. 2723 (2014).

73 Epic Sys. Corp. v. McKesson Techs., Inc., 133 S. Ct. 1520 (2013). 
go outside of the question presented regarding active inducement and addressed the single entity rule under $\S 271(\mathrm{a}) .{ }^{74}$

During oral argument, the Supreme Court seemed interested in the Federal Circuit's single-entity rule for $\$ 271$ (a), ${ }^{75}$ but in the decision, the Court only addressed the active inducement question. ${ }^{76}$ The Court rejected the Federal Circuit's attempt to manipulate $\$ 271(\mathrm{~b})$ to deal with the divided

74 See Brief for Respondents at 19-36, Limelight Networks, Inc. v. Akamai Techs., Inc., 134 S. Ct. 2111 (2014) (No. 12-786) (arguing that $\$ 271$ (a) was "fairly included" in the question presented and arguing the merits of divided infringement as its primary argument).

75 Many of the questions involved the ability to evade patent protection by having another party perform a step of the method, which is the $\$ 271$ (a) question, not $\$ 271$ (b). See, e.g., Transcript of Oral Argument at 5, Limelight, 134 S. Ct. 2111 (2014) (No. 12-786) (Chief Justice Roberts noting that "[a]ll you've got to do is find one step in the process and essentially outsource it or-or make it attractive for someone else to perform that particular step and you've essentially invalidated the patent."); $i d$. at 10 (Justice Ginsburg asking, "[D]idn't the parties brief, what is it, 271(1) or-and then the Federal Circuit decided it on sub (2)"); id. at 12-13 (Justice Kagan noting that "if [the Federal Circuit] did reach it a second time around and they decided well, now that this inducement theory is not available to us, we think that there is a real problem here . . so we're going to change what we think on the 271 (a) question, if they did that, it would be right to say it would render our opinion on the 271(b) question a nullity"); id. at 15 (Justice Alito noting that "you're asking us to decide a question ... that is . . . of no significance unless the ruling on (a) stands"); id. at 26 (Justice Sotomayor asking whether "there's some kind of method patents that simply cannot be drafted from the perspective of a single entity").

76 Limelight, 134 S. Ct. at 2120 (2014) ("Respondents ask us to review the merits of the Federal Circuit's Muniauction rule for direct infringement under $\S 271(\mathrm{a})$. We decline to do so today."). The Court noted that "the Federal Circuit will have the opportunity to revisit the $\$ 271$ (a) question if it so chooses." $I d$.

The Federal Circuit initially declined to revisit the $\S 271$ (a) issue en banc and remanded the case to the original panel, with a substitute judge due to the retirement of an original panel member. See Akamai Techs., Inc. v. Limelight Networks, Inc., 571 F. App'x 958, 958-59 (Fed. Cir. 2014) (en banc) (per curiam). The panel applied its prior single-entity rule and found no infringement, Akamai Techs., Inc. v. Limelight Networks, Inc., 786 F.3d 899, 903-04 (Fed. Cir. 2015), over a strong dissent from the new panel member, $i d$. at 915-32 (Moore, J., dissenting). The en banc court then unanimously rejected the panel's methodology and changed the rule for divided infringement under § 271(a). Akamai Techs., Inc. v. Limelight Networks, Inc., 797 F.3d 1020, 1023 (Fed. Cir. 2015). Specifically, the en banc court concluded " $[\mathrm{w}] \mathrm{e}$ will hold an entity responsible for others' performance of method steps in two sets of circumstances: (1) where that entity directs or controls others' performance, and (2) where the actors form a joint enterprise." $I d$. at 1022. Overall, the court left the inquiry rather open-ended: "Section 271(a) is not limited solely to principal-agent relationships, contractual arrangements, and joint enterprise, as the vacated panel decision held. Rather, to determine direct infringement, we consider whether all method steps can be attributed to a single entity." Id. at 1023 (footnote omitted). As to this particular case, the court concluded "liability under $\$ 271$ (a) can also be found when an alleged infringer conditions participation in an activity or receipt of a benefit upon performance of a step or steps of a patented method and establishes the manner or timing of that performance." Id. (citing Metro-Goldwyn-Mayer Studios Inc. v. Grokster, Ltd., 545 U.S. 913, 930 (2005)). 
infringement problem. ${ }^{77}$ The Supreme Court made clear that there must be an act of direct infringement, and thus a direct infringer, for a party to be liable for actively inducing infringement. ${ }^{78}$ The Court rejected the Federal Circuit's reasoning in less than flattering terms, noting that " $[\mathrm{t}]$ he Federal Circuit's analysis fundamentally misunderstands what it means to infringe a method patent."79 According to the Supreme Court, the Federal Circuit's approach "would deprive $\$ 271$ (b) of ascertainable standards. If a defendant can be held liable under $\S 271$ (b) for inducing conduct that does not constitute infringement, then how can a court assess when a patent holder's rights have been invaded?" 80 The Court's holding avoided other potential complications with the Federal Circuit's approach, such as significant public notice concerns $^{81}$ and the untethering of any territorial limits from $\S 271(\mathrm{~b}) .^{82}$

As a result, the Supreme Court reinstated the natural link between $\S 271$ (a) (and potentially other direct infringement provisions) and active inducement under $\S 271(\mathrm{~b})$. The various limitations of $\S 271$ (a) now limit the scope of active inducement as well. ${ }^{83}$

77 Limelight, 134 S. Ct. at 2115 ("This case presents the question whether a defendant may be liable for inducing infringement of a patent under 35 U.S.C. $\$ 271$ (b) when no one has directly infringed the patent under $\$ 271(\mathrm{a})$ or any other statutory provision. The statutory text and structure and our prior case law require that we answer this question in the negative.").

$78 I d$. at 2117 ("[T] here has simply been no infringement of the method in which respondents have staked out an interest, because the performance of all the patent's steps is not attributable to any one person. And, as both the Federal Circuit and respondents admit, where there has been no direct infringement, there can be no inducement of infringement under $\S 271(\mathrm{~b}) . ”)$.

$79 \quad I d$

$80 \quad$ Id

81 Mark D. Janis \& Timothy R. Holbrook, Patent Law's Audience, 97 Minn. L. Rev. 72, 118-20 (2012) (discussing advantages and disadvantages of the Federal Circuit's approach based on public notice concerns).

82 See generally Timothy R. Holbrook, The Potential Extraterritorial Consequences of Akamai, 26 Emory Int'L L. Rev. 499 (2012) (arguing that the Federal Circuit unintentionally had removed territorial limits and implicitly overruled NTP, Inc. v. Research in Motion, Ltd., 418 F.3d 1282, 1318 (Fed. Cir. 2005)).

83 On remand, the Federal Circuit-after a circuitous path-addressed the issue of direction and control. The Federal Circuit initially refused to take Akamai back en banc, and a panel of the court heard the case on remand. Akamai Techs., Inc. v. Limelight Networks, Inc., 571 Fed. App'x 958, 958-59 (Fed. Cir. 2014) (en banc) (per curiam). The panel upheld the same standard, with a sharp dissent by Judge Moore. Akamai Techs., Inc. v. Limelight Networks, Inc., 786 F.3d 899, 903-04 (Fed. Cir. 2015); id. at 915-32 (Moore, J., dissenting). The court subsequently granted rehearing en banc, Akamai Techs., Inc. v. Limelight Networks, Inc., 612 Fed. App'x 617, 617-18 (Fed. Cir. 2015) (en banc) (per curiam), and issued a succinct decision that broadened the circumstances when a party can be held liable for direct infringement in these divided infringement scenarios, Akamai Techs., Inc. v. Limelight Networks, Inc., 797 F.3d 1020, 1022-23 (Fed. Cir. 2015) (en banc) (per curiam). The court finally resolved all remaining issues before it in November 2015, although the litigation is ongoing. Akamai Techs., Inc. v. Limelight Networks, Inc., 805 F.3d 1368 (Fed. Cir. 2015). 


\section{A Return to-and Narrowing of-the Mental State Requirement in} Commil USA, LLC v. Cisco Systems, Inc.

Within one year, $\S 271$ (b) was back before the Supreme Court. The issue presented in Commil USA, LLC v. Cisco Systems, Inc. was seemingly narrow: whether an infringer's good faith belief that the patent at issue is invalid should negate the scienter requirement for inducing patent infringement. ${ }^{84}$ In Global-Tech, the Supreme Court held that knowledge both of the patent and that the induced acts constituted infringement were necessary for induced infringement. ${ }^{85}$ An accused infringer could have the requisite knowledge, however, if it willfully blinded itself to the existence of the patent. ${ }^{86}$ What if, however, the accused inducer had investigated that patent and came to believe, in good faith, that the patent was invalid, even if the induced acts infringed? Commil addressed whether such a good faith belief negated the scienter requirement and thus immunized the inducer from liability. ${ }^{87}$

The Federal Circuit held that such a belief was sufficient to negate the requisite mental state. The court reasoned that one cannot infringe an invalid patent. ${ }^{88}$ As such, "one could be aware of a patent and induce another to perform the steps of the patent claim, but have a good faith belief that the patent is not valid. Under those circumstances, it can hardly be said that the alleged inducer intended to induce infringement." 89 Consequently, such belief "may negate the specific intent to encourage another's infringement, which is required for induced infringement." 90

At oral argument at the Supreme Court, some of the Justices seemed sympathetic to the Federal Circuit's holding. For example, Justice Kagan noted the link between claim construction, infringement, and invalidity:

[S] uppose I have a product and I'm trying to figure out whether, if I sell this product, I'll have liability. And there are two ways to construe . . . a patent; one is narrow and one is broad. And if the patent is construed narrowly, I won't be infringing it. But if the patent is construed broadly, it's not valid .... So I have two possible defenses, depending on whether the patent is construed narrowly or the patent is construed broadly.

84135 S. Ct. 1920 (2015).

85 Glob.-Tech Appliances, Inc. v. SEB S.A., 131 S. Ct. 2060, 2068 (2011) ("[W]e now hold that induced infringement under $\$ 271$ (b) requires knowledge that the induced acts constitute patent infringement.").

86 Id. at $2070-71$.

87 Or, at least, only pre-suit liability. See infra Section III.B.

88 See Commil USA, LLC v. Cisco Sys., Inc., 720 F.3d 1361, 1368 (Fed. Cir. 2013), vacated and remanded, 135 S. Ct. 1920 (2015).

$89 I d$.

90 Id. The court noted that the district courts that had considered the issue had reached the same conclusion. Id. Judge Newman dissented, noting that "[a] good-faith belief of patent invalidity may be raised as a defense to willfulness of the infringement, but it is not a defense to the fact of infringement." Id. at 1373 (Newman, J., concurring in part and dissenting in part). 
Now, Global-Tech says that I have a good faith defense as to non-infringement, but you're suggesting I don't have that good faith defense as to invalidity. And I guess I don't understand quite why that would make sense in the context I'm talking about . . . .91

At other times, though, the Justices seemed skeptical about affording a defense based on an ultimately incorrect affirmative defense. ${ }^{92}$

Interestingly, both Commil and the United States as amicus argued that neither a good faith belief in invalidity nor non-infringement would negate the scienter requirement for inducement because the inducer need not have knowledge that the induced acts constitute infringement. ${ }^{93}$ Commil's arguments were understandable because it was making the arguments needed to win the case: eliminating the scienter requirement would be a clean win. The United States' position was surprising, however, given the clear language in Global-Tech that induced infringement required knowledge that the induced acts infringed the patent. ${ }^{94}$ Notably, the United States did not participate in the Global-Tech case in any form, neither through an amicus brief nor at oral argument. The norm in patent cases at the Supreme Court is for the United States to participate as an amicus. ${ }^{95}$ There is nothing in the pub-

91 Transcript of Oral Argument at 9-10, Commil USA, LLC v. Cisco Sys., Inc., 135 S. Ct. 1920 (2015) (No. 13-896).

$92 I d$. at 31 (Chief Justice Roberts stating that "if you regard the patent as law, it seems to me that your position is really just ignorance of the law as an excuse"); $i d$. at 33 (Justice Kagan stating that "if the contract was valid, you lose even though you thought the contract was invalid. And so, too, here it would seem to me").

93 Brief of Petitioner at 21-44, Commil USA, LLC v. Cisco Sys., Inc., 720 F.3d 1361 (Fed. Cir. 2013) (No. 13-896); Brief for the United States as Amicus Curiae Supporting Petitioner at 9-18, Commil, 135 S. Ct. 1920 (No. 13-896).

94 Glob.-Tech Appliances, Inc. v. SEB S.A., 131 S. Ct. 2060, 2068 (2011) (“Accordingly, we now hold that induced infringement under $\$ 271(\mathrm{~b})$ requires knowledge that the induced acts constitute patent infringement."). It is also surprising given that the patent act specifically contemplates opinions of counsel having relevance in assessing active inducement. See 35 U.S.C. $\$ 298$ (2012) ("The failure of an infringer to obtain the advice of counsel with respect to any allegedly infringed patent, or the failure of the infringer to present such advice to the court or jury, may not be used to prove . . . that the infringer intended to induce infringement of the patent.”). This provision was added to the patent statute by the America Invents Act (AIA). See America Invents Act, Pub. L. No. 112-29, 125 Stat. 284, § 17 (2011) (codified at 35 U.S.C. $§ 298$ ).

95 Since the 2004 term, the United States participated as amicus in each of the following patent cases at the Supreme Court: Kimble v. Marvel Entertainment, LLC, 135 S. Ct. 2401 (2015); Teva Pharmaceutical USA, Inc. v. Sandoz, Inc., 135 S. Ct. 831 (2015); Alice Corp. Pty. Ltd. v. CLS Bank International, 134 S. Ct. 2347 (2014); Nautilus, Inc. v. Biosig Instruments, Inc., 134 S. Ct. 2120 (2014); Limelight Networks, Inc. v. Akamai Technologies, Inc., 134 S. Ct. 2111 (2014); Octane Fitness, LLC v. ICON Health E Fitness, Inc., 134 S. Ct. 1749 (2014); Highmark Inc. v. Allcare Health Management System, Inc., 134 S. Ct. 1744 (2014); Medtronic, Inc. v. Mirowski Family Ventures, LLC., 134 S. Ct. 843 (2014); Ass'n for Molecular Pathology v. Myriad Genetics, Inc., 133 S. Ct. 2107 (2013); Bowman v. Monsanto Co., 133 S. Ct. 1761 (2013); Caraco Pharmaceutical Laboratories, Ltd. v. Novo Nordisk A/S, 132 S. Ct. 1670 (2012); Mayo Collaborative Services v. Prometheus Laboratories, Inc., 132 S. Ct. 1289 (2012); Microsoft Corp. v. i4i Ltd. Partnership, 131 S. Ct. 2238 (2011); Board of Trustees of Leland Stanford Junior 
lic record explaining the government's conspicuous absence from GlobalTech, but it explains why the United States took this opportunity to now push back against the Court's holding. The Supreme Court, though, was not impressed with this position at oral argument. ${ }^{96}$

Ultimately the Supreme Court rejected Commil's and the United States' efforts to overrule Global-Tech. ${ }^{97}$ The Court made clear that the inducer must be aware that the induced acts are infringing:

Qualifying or limiting [ Global-Tech's] holding, as the Government and Commil seek to do, would lead to the conclusion, both in inducement and contributory infringement cases, that a person, or entity, could be liable even though he did not know the acts were infringing. In other words, even if the defendant reads the patent's claims differently from the plaintiff, and that reading is reasonable, he would still be liable because he knew the acts might infringe. Global-Tech requires more. It requires proof the defendant knew the acts were infringing. And the Court's opinion was clear in rejecting any lesser mental state as the standard. ${ }^{98}$

The Court thus emphatically closed the door on efforts to end-run GlobalTech.

Although the Court did not go as far as requested by the United States, ultimately the Court did reject the Federal Circuit's position, drawing a line between a good faith belief that the induced acts did not infringe and one that the patent is invalid. ${ }^{99}$ The Court held that "because infringement and validity are separate issues under the Act, belief regarding validity cannot negate the scienter required under $\S 271$ (b)."100 To hold otherwise "would conflate the issues of infringement and validity." 101 The Court also felt that "[a]llowing this new defense would ... undermine" the statutory presump-

University v. Roche Molecular Systems, Inc., 131 S. Ct. 2188 (2011); Quanta Computer, Inc. v. LG Electronics, Inc., 553 U.S. 617 (2008); Microsoft Corp. v. ATEST Corp., 550 U.S. 437 (2007); KSR International Co. v. Teleflex Inc., 550 U.S. 398 (2007); MedImmune, Inc. v. Genentech, Inc., 549 U.S. 118 (2007); Laboratory Corp. of America Holdings v. Metabolite Laboratories, Inc., 548 U.S. 124 (2006); eBay Inc. v. MercExchange, L.L.C., 547 U.S. 388 (2006); Illinois Tool Works Inc. v. Independent Ink, Inc., 547 U.S. 28 (2006); Unitherm Food System, Inc. v. Swift-Eckrich, Inc., 546 U.S. 394 (2006); and Merck KGaA v. Integra Lifesciences I, Ltd., 545 U.S. 193 (2005). Which is to say, basically all of the patent cases, except for Global-Tech.

96 See, e.g., Transcript of Oral Argument at 17-18, Commil USA, LLC v. Cisco Sys., Inc., 135 S. Ct. 1920 (2015) (No. 13-896) (Justice Kagan noting, "we just said, we now hold that induced infringement under 271(b) requires knowledge that the induced acts constitute patent infringement. And your brief essentially puts a 'not' in that sentence."); $i d$. at 18-19 (Justice Scalia asking "[a]re we that dumb, that . . . we would say those two things in successive sentences?”); $i d$. at 25 (Chief Justice Roberts noting that "[w] hat you just said does sound like an argument that Global-Tech was-was wrong.").

97 Commil, 135 S. Ct. at 1927 ("Accepting the Government and Commil's argument would require this Court to depart from its prior holding.").

$98 \quad I d$. at 1928.

$99 I d$.

$100 I d$.

$101 I d$. 
tion that an issued patent's claims are valid. ${ }^{102}$ Acknowledging that one cannot infringe an invalid patent, the Court nevertheless emphasized that "[v]alidity and infringement are distinct issues, bearing different burdens, different presumptions, and different evidence." 103

The Court also relied on a variety of pragmatic reasons for rejecting the Federal Circuit's rule. The Court emphasized a number of options that potential inducers had to challenge the patent's validity if they held such a belief. For example, parties could file a declaratory judgment action or avail themselves of the various post-issuance administrative proceedings at the United States Patent and Trademark Office (PTO). ${ }^{104}$ The Court was also concerned that an accused inducer could easily evade liability by offering a colorable invalidity argument: "accused inducers would likely find it easier to prevail on a defense regarding the belief of invalidity than noninfringement." 105 Exploration of such a good faith belief would also "increase discovery costs and multiply the issues the jury must resolve. Indeed, the jury would be put to the difficult task of separating the defendant's belief regarding validity from the actual issue of validity." 106

The Court concluded with a somewhat odd rumination on the existence of patent assertion entities (PAEs), often referred to pejoratively as "patent trolls." 107 The majority appears to embrace the normative view that PAEs are categorically problematic, noting their behavior can "impose a 'harmful tax on innovation." "108 While admitting that the issue of PAEs is not an issue in

102 Id. at 1928-29; see also 35 U.S.C. $\$ 282(\mathrm{a})$ (2012) ("A patent shall be presumed valid. . . The burden of establishing invalidity of a patent or any claim thereof shall rest on the party asserting such invalidity.").

103 Commil, 135 S. Ct. at 1929 (quoting Commil USA, LLC v. Cisco Sys., Inc., 720 F.3d 1361, 1374 (Newman, J., concurring in part and dissenting in part)).

$104 I d$.

105 Id. at 1930.

$106 I d$

107 Indeed, it was rather startling to find the use of the pejorative "patent troll" term appear in Justice Scalia's dissent. See id. at 1932 (Scalia, J., dissenting) ("I may add, however, that if the desirability of the rule we adopt were a proper consideration, it is by no means clear that the Court's holding, which increases the in terrorem power of patent trolls, is preferable."). Whether patent assertion entities are categorically a problem is the subject of debate. See, e.g., Colleen V. Chien, From Arms Race to Marketplace: The Complex Patent Ecosystem and Its Implications for the Patent System, 62 Hastings L.J. 297, 328 (2010); Robin Feldman \& Mark A. Lemley, Do Patent Licensing Demands Mean Innovation?, 101 Iowa L. Rev. 137 (2015); Ryan T. Holte, Trolls or Great Inventors: Case Studies of Patent Assertion Entities, 59 Sт. Louis U. L.J. 1 (2015); Kristen Osenga, Formerly Manufacturing Entities: Piercing the "Patent Troll" Rhetoric, 47 Conn. L. Rev. 435 (2014); Timothy R. Holbrook, Opinion, Not All Patent Trolls Are Demons, CNN (9:08 AM, Feb. 21, 2014), http://www.cnn.com/2014/ 02/21/opinion/holbrook-patent-trolls-demons/; Robin Feldman et al., The AIA 500 Expanded: The Effects of Patent Monetization Entities, (U.C. Hastings Research Paper No. 45, 2013), http://papers.ssrn.com/sol3/papers.cfm?abstract_id=2247195.

108 Commil, 135 S. Ct. at 1930 (citing Prepared Statement of the Fed. Trade Comm'n on Discussion Draft of Patent Demand Letter Litig. Before the Subcomm. on Commerce, Mfg., and Trade of the H. Comm. on Energy and Commerce, 113th Cong. 2 (2014)). 
the case, the Court nevertheless felt it "necessary and proper to stress that district courts have the authority and responsibility to ensure frivolous cases are dissuaded." 109 Such advisory language appears to be the Court's effort to step into the fray on PAEs and the proposed Congressional legislation to address these concerns. The section, however, is an odd appendage to the decision.

\section{The Impact of the Quiet Revolution: Commil's Move Away from Lear's Policy of Encouraging Patent Challenges in Court}

The Supreme Court's recent engagement has been rather surprising, given the existence of the Federal Circuit. Nevertheless, most of the Court's decisions have come down against patents. Such suspicion of the exclusive power of patents, however, is not of recent vintage. The Supreme Court has generally expressed concern, and indeed, "antipathy," at times to patents. ${ }^{110}$ This Section explores this hostility and the Court's primary way of dealing with invalid patents: encouraging validity challenges in the courts. As this Section explains, by reducing the incentive for actors to enter a market when they believe a patent is invalid, the Court in Commil has undermined this policy.

\section{A. The Mixed Overall Impact of the Tetralogy}

For some unknown reason, the Supreme Court's reworking of active inducement has not garnered the attention of its other recent work, particularly eligible subject matter. Admittedly, active inducement will not have the dramatic impact on patent validity that the subject matter cases have had. Nevertheless, this quiet revolution bears further exploration and consideration.

The net impact of these cases generally favors patent holders, making it easier for them to demonstrate liability under active inducement. Grokster demonstrates a rather strong concern with infringers who flout intellectual property rights. Indeed, the Court went out of its way to embrace active inducement as a means of combatting copyright infringement on peer-topeer networks. Global-Tech is consistent in this regard. Although the Court rejected the Federal Circuit's more capacious "deliberate indifference" standard, the Court's "willful blindness" rule also offers considerable protection to patent owners. The Court could have adopted a requirement for actual knowledge of the particular patent at issue. If they had done so, inducers could easily have "played ostrich" and avoided liability. ${ }^{111}$ Instead, the Court avoided this problem with the "willful blindness" standard, thereby encourag-

109 Id

110 Deepsouth Packing Co. v. Laitram Corp., 406 U.S. 518, 530 (1972) ("Moreover, we must consider petitioner's claim in light of this Nation's historical antipathy to monopoly .....").

111 Or, if the proposal below is adopted, avoided liability for past damages but not prospective relief. See infra Section III.B. 
ing potential infringers to inquire about patents. ${ }^{112}$ Limelight seems a bit of a one-off decision, correcting an erroneous and unjustified alteration in the law of active inducement. It also represents a contraction of the availability of inducement as a theory by limiting it only to circumstances where there is an actual direct infringer. So, of the four cases, this one does make it more difficult for patent owners to prevail. Finally, Commil eliminates a potential defense to active inducement, affording $\$ 271$ (b) considerably more potency as a tool to be used by patent holders.

Closer scrutiny of Commil, particularly when coupled with Global-Tech, reveals considerable tension between the two decisions. Arguably the issue in Commil is quite narrow. The issue of a good faith belief of the invalidity of the relevant patent would only arise when the accused inducer fails actually to invalidate the patent in litigation. If the accused inducer had been correct about the patent's validity, then she would have prevailed at trial. Additionally, the accused inducer would have had to obtain some sort of advice of counsel regarding the patent's validity at some point prior to the lawsuit. This combination of requirements means the issue may not arise frequently.

Nevertheless, Commil is significant beyond its seemingly narrow issue because it marks a step away from the Supreme Court's historical suspicion of the validity of most patents and its interest in encouraging parties to challenge patents through litigation. Commil represents an underappreciated departure from this policy preference, as the balance of the next Section elaborates.

\section{B. Lear and the Supreme Court's Encouragement of Patent Validity Challenges}

Much of the current criticism of the patent system involves the quality of issued patents. Many believe that the PTO is issuing too many "bad" patents, however that term may be defined. ${ }^{113}$ These concerns, however, are nothing new. The Supreme Court squarely addressed concerns about invalid patents over fifty years ago in Lear, Inc. v. Adkins. ${ }^{114}$ Similar to Commil, the issue in Lear was relatively narrow: whether a licensee of a patent was precluded from challenging the validity of that patent through the doctrine of licensee estoppel. ${ }^{115}$ The Supreme Court concluded that there was no such preclusion, eliminating the doctrine and allowing licensees to challenge the validity of the licensed patents.

112 I elaborate on the considerable importance of this dynamic. See infra Section II.C.

113 Lisa Rein, Patent and Trademark Office Doesn't Know if Examiners Are Doing Their Jobs, Watchdog Says, Wash. Post: Fed. Eye (Apr. 14, 2015), http://www.washingtonpost.com/ blogs/federal-eye/wp/2015/04/14/the-u-s-patent-and-trademark-office-doesnt-know-if-pat ent-examiners-are-doing-their-jobs-watchdog-says/. For a discussion of patent quality, see generally Christi J. Guerrini, Defining Patent Quality, 82 Fordham L. Rev. 3091 (2014).

114395 U.S. 653 (1968).

115 See id. at 661-62 ("Since the California Supreme Court's construction of the 1955 licensing agreement is solely a matter of state law, the only issue open to us is raised by the court's reliance upon the doctrine of estoppel to bar Lear from proving that Adkins' ideas were dedicated to the common welfare by federal law."). 
In so doing, the Supreme Court revealed its suspicions regarding the validity of many issued patents. The Court acknowledged its concerns with immunizing patents from challenge by a licensee given the nature of ex parte review at the PTO:

A patent, in the last analysis, simply represents a legal conclusion reached by the Patent Office. Moreover, the legal conclusion is predicated on factors as to which reasonable men can differ widely. Yet the Patent Office is often obliged to reach its decision in an ex parte proceeding, without the aid of the arguments which could be advanced by parties interested in proving patent invalidity. Consequently, it does not seem to us to be unfair to require a patentee to defend the Patent Office's judgment when his licensee places the question in issue, especially since the licensor's case is buttressed by the presumption of validity which attaches to his patent. ${ }^{116}$

These concerns about the ex parte examination process suggest that the Court doubted the validity of many of the patents issued by the PTO. As a result, litigation is an appropriate way to weed out the invalid patents. This policy of encouraging patent challenges through litigation becomes more readily apparent with the Court's invocation of the public interest in justifying its rejection of licensee estoppel:

Surely the equities of the licensor do not weigh very heavily when they are balanced against the important public interest in permitting full and free competition in the use of ideas which are in reality a part of the public domain. Licensees may often be the only individuals with enough economic incentive to challenge the patentability of an inventor's discovery. If they are muzzled, the public may continually be required to pay tribute to wouldbe monopolists without need or justification. ${ }^{117}$

The Court accordingly recognized the need to permit challenges to invalid patents in the context of patent litigation.

The Court's skepticism of the validity of many patents is not terribly surprising, particularly given that era. The Court similarly had embraced collateral estoppel with respect to patent validity, such that effectively, once a party manages to invalidate a patent claim, it is invalid as to the world. ${ }^{118}$ The Court relied extensively upon Lear and its policy concerns to justify removing the mutuality requirement. ${ }^{119}$ The Court subsequently noted the "desirability of encouraging licensees to challenge the validity of patents, to further the strong federal policy that only inventions which meet the rigorous requirements of patentability shall be withdrawn from the public domain." 120

Facilitating patent challenges generally had continued into the recent era of Supreme Court intervention in patent law. In MedImmune, Inc. $v$. Genentech, Inc., the Court extended the reasoning of Lear to permit a licensee

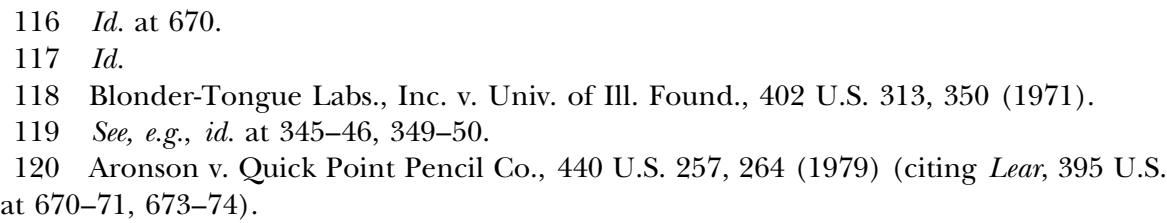


who had not breached the license to sue to challenge the patent under the Declaratory Judgment Act. ${ }^{121}$ The Federal Circuit had held there was no case or controversy because the licensee did not possess a reasonable apprehension of being sued for patent infringement due to the existence of the license. ${ }^{122}$ The Court rejected this formalistic rule, ${ }^{123}$ instead embracing a more contextual analysis that was more consistent with declaratory judgment jurisprudence outside of patent law. ${ }^{124}$ The Court specifically held that a licensee "was not required . . . to break or terminate its . . . license agreement before seeking a declaratory judgment in federal court that the underlying patent is invalid, unenforceable, or not infringed." 125

MedImmune is an important extension of Lear. That decision made it easier for licensees to bring validity challenges, consistent with Lear's rejection of licensee estoppel. Not only are licensees no longer estopped from challenging the patent's validity under Lear, but now they no longer need to "bet the farm" by breaching the license to do so. ${ }^{126}$ This is true even though it may be difficult, if not impossible, for the patentee to sue the licensee absent a breach. ${ }^{127}$ MedImmune, therefore, created some asymmetry between the patent owner and the licensee. ${ }^{128}$

More recently, in Medtronic, Inc. v. Mirowski Family Ventures, LLC, the Court again extended the interest in generating patent validity challenges, at least by licensees. ${ }^{129}$ In Medtronic, the Federal Circuit flipped the typical bur-

121549 U.S. 118 (2007).

122 MedImmune, Inc. v. Genentech, Inc., 427 F.3d 958, 965 (Fed. Cir. 2005) ("The district court did not err in holding that MedImmune, since under no threat or apprehension of suit, did not have standing to bring a declaratory challenge to the Cabilly II patent.”), rev'd and remanded, 549 U.S. 118 (2007).

123 MedImmune, 549 U.S. at 132 n.11 (citing Cardinal Chem. Co. v. Morton Int'l, Inc., 508 U.S. 83, 98 (1993); Md. Casualty Co. v. Pac. Coal \& Oil Co., 312 U.S. 270, 273 (1941); Aetna Life Ins. Co. v. Haworth, 300 U.S. 227, 239 (1937); Teva Pharm. USA, Inc. v. Pfizer, Inc., 395 F.3d 1324, 1333 (Fed. Cir. 2005)).

$124 I d$. at 127 ("Aetna and the cases following it do not draw the brightest of lines between those declaratory-judgment actions that satisfy the case-or-controversy requirement and those that do not. . . B Basically, the question in each case is whether the facts alleged, under all the circumstances, show that there is a substantial controversy, between parties having adverse legal interests, of sufficient immediacy and reality to warrant the issuance of a declaratory judgment.'” (quoting Md. Casualty Co., 312 U.S. at 273)).

$125 I d$. at 137.

$126 I d$. at 129 (citing Vill. of Euclid v. Ambler Realty Co., 272 U.S. 365 (1926); Terrace v. Thompson, 263 U.S. 197, 216 (1923); Ex parte Young, 209 U.S. 123 (1908) ("Given this genuine threat of enforcement, we did not require, as a prerequisite to testing the validity of the law in a suit for injunction, that the plaintiff bet the farm, so to speak, by taking the violative action.")).

127 Medtronic Inc. v. Bos. Sci. Corp., 695 F.3d 1266, 1273 (Fed. Cir. 2012), rev'd and remanded, Medtronic Inc. v. Mirowski Family Ventures, LLC, 134 S. Ct. 843 (2014).

128 The Supreme Court may have provided some more balance in a subsequent trademark case. See Already, LLC v. Nike, Inc., 133 S. Ct. 721, 727-28 (2013) (holding that an "unconditional and irrevocable" covenant not to sue satisfied the voluntary cessation doctrine, mooting the case).

129134 S. Ct. 843 (2014). 
den of proof in a patent case, holding that, in a declaratory judgment case, the licensee had to prove that it did not infringe if it had not breached the license. ${ }^{130}$ The Federal Circuit justified this holding on the asymmetry created by MedImmune:

In this case, as sanctioned by MedImmune, the continued existence of the license precludes the very infringement counterclaim that normally would impose the burden of proving infringement on the patentee. Here, Medtronic is shielded from any liability for infringement by its license. And MFV has not asserted a claim of infringement, nor could it because of the license. Thus, while Medtronic's suit for declaratory judgment undoubtedly rests upon the infringement provisions laid out in $\S 271$, the relief it seeks relates directly to its obligations under the license. ${ }^{131}$

The Supreme Court rejected this burden shifting, holding that "the burden of persuasion is with the patentee, just as it would be had the patentee brought an infringement suit." 132 The Court reasoned that the Declaratory Judgment Act is merely procedural and does not change any substantive rights. ${ }^{133}$ The burden of proof, however, is substantive in nature, so the burden of proving infringement remains with the patentee. ${ }^{134}$ In reaching this conclusion, the Court relied upon the public's "paramount interest in seeing that patent monopolies . . . are kept within their legitimate scope."135 Because "“[1]icensees may often be the only individuals with enough economic incentive' to litigate questions of a patent's scope," 136 the Court concluded that "general public interest considerations . . . do not favor a change in the ordinary rule imposing the burden of proving infringement upon the patentee." 137

The Supreme Court's policy thus appeared quite clear: there is a strong public interest in having the scope of patents assessed, particularly with respect to validity. Invalid patents create barriers to competition that are not justified. The Supreme Court therefore generally encouraged patent validity challenges from licensees because they may be one of the few with the economic motivation to do so.

But what about other market actors who also might have such an incentive to challenge arguably invalid patents? One would think that the Court

130 Bos. Sci. Corp., 695 F.3d at 1274 ("[T] his court holds that in the limited circumstance when an infringement counterclaim by a patentee is foreclosed by the continued existence of a license, a licensee seeking a declaratory judgment of noninfringement and of no consequent liability under the license bears the burden of persuasion.”).

131 Id. at 1273.

132 Mirowski Family Ventures, 134 S. Ct. at 849.

$133 I d$.

$134 I d$

135 Id. at 851 (quoting Precision Instrument Mfg. Co. v. Auto. Maint. Mach. Co., 324 U.S. 806, 816 (1945)).

136 Id. at 852 (quoting Lear, Inc. v. Adkins, 395 U.S. 653, 670 (1969)).

$137 I d$. 
would want to encourage similar challenges. That is exactly what Global-Tech did, ${ }^{138}$ albeit perhaps unintentionally.

\section{How Global-Tech 's "Willful Blindness" Standard Advanced the Policy of Lear}

Until now, the literature-and apparently the courts-failed to appreciate that Global-Tech actually facilitates the policies of Lear and its progeny to encourage the challenge of potentially invalid patents. ${ }^{139}$ The "willful blindness" standard of Global-Tech created an incentive for potential infringers to review patents instead of burying their head in the sand. By encouraging market participants to review patents, such parties would make an assessment of whether they infringe the patent and whether the patent is invalid. If they believe the patent is invalid, one would hope they enter the market, potentially triggering a validity challenge. If their entry is chilled, even though they believe the patent is invalid, then the mere presence of the patent is discouraging pro-competitive behavior. Having would-be competitors enter the market, potentially triggering a validity challenge, would be consistent with Lear and indeed provides another category of those who might now have the economic incentive to challenge a patent. This subsection elaborates this unintended consequence of Global-Tech.

Patent law's strict liability regime operates under a quasi-constructive notice system. Ignorance of a patent does not excuse someone from infringement, in large part because patents are public documents. One hopes that persons will actually review patents, both to learn from their disclosure and to assess whether they infringe them. ${ }^{140}$ This dynamic in part justifies the strict liability regime that we have for direct infringement. Potential inducers should also review patents to assess their potential liability. Given the knowledge requirement for inducing infringement, one can only be liable for inducement if she has actual knowledge of the patent or is willfully ignorant of it.

An important collateral consequence of the Supreme Court's adoption of the willful blindness standard in Global-Tech is that companies now have a stronger incentive to search for and review patents. Before Global-Tech, parties could have avoided liability for inducing infringement by simply ignoring patents altogether, burying their heads in the proverbial sand. If a party did not have actual knowledge of the particular patent at issue, then by definition they could not be liable for inducing infringement. If $\S 271(\mathrm{~b})$ required

138 Glob.-Tech Appliances, Inc. v. SEB S.A., 131 S. Ct. 2060, 2070 (2011).

139 Parts of this Section are based on the arguments I presented on behalf of myself and fifteen other law professors in an amici brief filed in Commil. See generally Brief Amici Curiae for Sixteen Intellectual Property Law Professors in Support of the Respondent, Commil USA, LLC v. Cisco Sys., Inc., 135 S. Ct. 1920 (2015) (No. 13-896).

140 See Jason Rantanen, Patent Law's Disclosure Requirement, 45 Loy. U. CHI. L.J. 369, 370 (2013). There are, of course, complications to this theory. See generally Janis \& Holbrook, supra note 81, at 86-89 (discussing the increasing complexity of the audience for patents and patent law). 
actual knowledge of the patent, then someone could avoid inducement liability by simply never looking for any relevant patents.

Global-Tech changed that dynamic because such ostrich-like behavior now will not immunize the party. The Court held that the knowledge requirement for inducement of infringement under $\S 271$ (b) is satisfied if the defendant "subjectively believe[s] that there is a high probability that a fact exists," i.e., that there is a patent, and the defendant "take[s] deliberate actions to avoid learning of that fact." 141 The Court reasoned that the law should not "protect[ ] parties who actively encourage others to violate patent rights and who take deliberate steps to remain ignorant of those rights despite a high probability that the rights exist and are being infringed."142

By adopting the willful blindness doctrine, the Court created an incentive for actors to look for patents and to ascertain whether their actions constitute infringement. Under Global-Tech, even if they don't look for patents, they can be found to have the requisite knowledge of the patent if they willfully blind themselves to the patent's existence. Moreover, by not reviewing the patents, they will deny themselves the opportunity to develop a good faith belief regarding infringement and invalidity. After Global-Tech, there is now a stronger incentive to search for and review patents: better to look and develop a good faith belief than not to look and risk infringement liability through the willful blindness doctrine. Potential inducers "will not suffer a negative inference if they ultimately decide not to rely on those opinions." 143 Justice Kennedy, a dissenter in Global-Tech, realized this dynamic in the Commil oral argument, where he noted that "the whole point of Global-Tech was inquiry was encouraged."144

Commil, however, undermines this policy of inquiry and, as such, steps back from the Court's long-standing policy of challenging the validity of patents as articulated in Lear.

\section{Critique of Commil and Its Implicit Rejection of That Policy Interest}

The Supreme Court ultimately concluded that a good faith belief that the relevant patent is invalid does not negate the mental state required to induce infringement. As such, the Court has undermined the appropriate incentive it created in Global-Tech. The incentive is no longer as strong because a good faith belief in invalidity will not protect a potential inducer. Moreover, on the margins, such inducers may opt not to enter the market at all, creating anticompetitive consequences. Ultimately, the Court's decision

141 Glob.-Tech, 131 S. Ct. at 2070.

$142 I d$. at 2070 n.8; see also Kristin M. Hagen, Eyes Wide Shut: Induced Patent Infringement and the Willful Blindness Standard, 17 MarQ. Intell. Prop. L. Rev. 305, 317 (2013).

143 Richard M. Marsh Jr., The Aftermath of Akamai: Induced Infringement and Opinions of Counsel, 7 LANDSLIDE 29, 30 (2015) (discussing 35 U.S.C. \$ 298, which states that failing to present "the advice of counsel with respect to any allegedly infringed patent . . . to the court or jury[ ] may not be used to prove that the accused infringer . . . intended to induce infringement of the patent").

144 Transcript of Oral Argument, supra note 91, at 14. 
in Commil can be criticized on a number of bases, which this subsection explores.

1. The Court's Decision Reflects an Artificial Bifurcation of Invalidity and Infringement

The Supreme Court, looking at the patent statute, treated invalidity and infringement as completely distinct issues. They are not, and the Court's holding reflects an artificial bifurcation of invalidity and infringement that does not exist in practice. A patent's validity often depends on the construction afforded the relevant patent claim by the judge. Broadly construed claims are more likely to encounter validity issues. When a court construes a claim broadly, it is more likely to run afoul of the prior art, potentially being invalidated as anticipated or obvious. ${ }^{145}$ Moreover, when a court construes a claim broadly, there must be even more support in the patent's disclosure to support such breadth; otherwise the claim may be invalid for lack of an adequate written description of the invention or sufficiently enabling disclosure. ${ }^{146}$

The Federal Circuit itself has noted the "catch-22" when patentees argue for a broad claim construction that ensnares the accused infringer's device, only to have the court invalidate the claim as a result. ${ }^{147}$ For example, the court has noted the "irony of this situation," where the patentee "successfully pressed to have its claims include a jacketless system, but, having won that battle, it then had to show that such a claim was fully enabled, a challenge it could not meet. The motto, 'beware of what one asks for,' might be applicable here."148 Relatedly, the Federal Circuit has also articulated a canon of

145 See 35 U.S.C. $\$ \S 102,103$ (2012). Congress recently amended the Patent Act to change the definition of prior art for both anticipation and obviousness purposes. The America Invents Act moved the United States to a "first-to-file" system, which makes the relevant date for assessing anticipation and obviousness, with some exceptions, the filing date of the patent application. Under the 1952 Patent Act, the relevant date for most purposes was the date of invention. See Timothy R. Holbrook, Patent Anticipation and Obviousness as Possession, 65 EмоRY L.J. (forthcoming 2016) (manuscript at 7-8), http://pa pers.ssrn.com/sol3/papers.cfm?abstract_id=2579715.

14635 U.S.C. $\$ 112$ (a) (requiring a written description of the invention and a disclosure that enables a person skilled in the art to make and use the claimed invention); see also generally Timothy R. Holbrook, Patents, Presumptions, and Public Notice, 86 InD. L.J. 779, 802-03 (2011) (discussing the link between claim construction, claim scope, and disclosure obligations).

147 See, e.g., Auto. Techs. Int'l, Inc. v. BMW of N.A., Inc., 501 F.3d 1274, 1285 (Fed. Cir. 2007); Liebel-Flarsheim Co. v. Medrad, Inc., 481 F.3d 1371, 1380 (Fed. Cir. 2007). For an argument that the Federal Circuit inappropriately prefers invalidity determinations over non-infringement determinations, see Holbrook, supra note 146, at 803 (" $[\mathrm{I}] \mathrm{t}$ would seem more appropriate, if we do value patents, for the courts to err on the side of offering narrower claim constructions that may result in noninfringement, but nevertheless preserve validity. The patentee should not be punished merely for advocating a legal position. By adopting this catch-22 approach, the Federal Circuit has created an unwarranted bias against patents." (footnote omitted)).

148 Liebel-Flarsheim, 481 F.3d at 1380. 
claim construction-one that is admittedly rarely used ${ }^{149}$ - that suggests a court should construe a patent claim to retain its validity if reasonably possible. ${ }^{150}$

The Supreme Court was aware of this dynamic but chose to ignore it. ${ }^{151}$ In so doing, the Court ignored the realities of patent litigation, instead adopting a stilted statutory construction that artificially bifurcated infringement and invalidity and ignored the important lever that claim construction plays in both circumstances. Justice Scalia correctly recognized the Court's artificial bifurcation, observing in dissent that, while the majority "notes that the Patent Act treats infringement and validity as distinct issues," the distinction, while "true[,] . . . is also irrelevant." 152

\section{The Supreme Court's Decision Undermines Global-Tech and Reflects a} Retreat from Lear's Policy of Encouraging Patent Challenges

More importantly, the Supreme Court's rejection of the good faith belief regarding validity to negate the intent requirement undermines the laudable side-effect of Global-Tech. By eliminating good faith defense with respect to validity, review of a potential patent now may nevertheless result in liability, reducing the incentive to review them to begin with. From the perspective of a potential inducer, there is no difference between a determination that either the conduct is non-infringing or the patent is invalid: there will be no liability for inducing the relevant allegedly infringing acts. As Limelight made clear, there must be a direct infringer for there to be induced infringement, and there can be no direct infringer of an invalid patent.

The Court's bifurcation of infringement and invalidity, therefore, belies the real-world consequences of a determination of non-infringement or invalidity. In either scenario, there would be no liability for inducing infringement, which is all a potential market actor cares about. From the ex ante perspective, a party who has investigated a patent and thinks there will not be infringement or that the patent is invalid would believe that their activities would not trigger liability. Permitting liability for inducing infringement in the context of a good faith belief that the patent is invalid undermines the benefits of Global-Tech. A party that takes the initiative to proactively search for patents and to determine in good faith whether its conduct will result in liability now may be exposed to liability even if she believes the patent is invalid, reducing the incentive to incur the cost to perform such a review at all.

149 Phillips v. AWH Corp., 415 F.3d 1303, 1327 (Fed. Cir. 2005) (en banc) (citing Nazomi Commc'ns, Inc. v. ARM Holdings, PLC, 403 F.3d 1364, 1368-69 (Fed. Cir. 2005)).

150 Id. (citing Nazomi Commc'ns, 403 F.3d at 1368-69). For an argument that this canon should be given more robust application, see Timothy R. Holbrook, Possession in Patent Law, 59 S.M.U. L. REv. 123, 157-59 (2006).

151 See supra note 91 and accompanying text.

152 Commil USA, LLC v. Cisco Sys., Inc., 135 S. Ct. 1920, 1931 (2015) (Scalia, J., dissenting). 
Not only does elimination of the good faith belief as a defense undermine the benefits of Global-Tech, it consequently also undermines the policy articulated by this Court in favor of bringing challenges to likely invalid patents through litigation. In Lear, the Court emphasized a "strong federal policy favoring free competition in ideas which do not merit patent protection." 153 If a party believes a patent is invalid, then we should want them to enter the market and, if sued, to challenge the patent they believe to be invalid.

The Court has recognized that there is a need for incentives to challenge potentially invalid patents. Licensees are one group with an economic incentive to challenge the patent's validity, but would-be competitors could also have sufficient incentive. Encouraging the challenge of patents believed to be invalid is important to clear markets of inappropriately issued patents. Invalidation of a patent, in contrast to a non-infringement determination, is, in many respects, a public good that may be undersupplied. Securing an invalidity judgment costs the accused infringer but benefits everyone in the market. ${ }^{154}$ The patent becomes invalid as to the world, including the accused infringer's competitors who will not have borne the cost of the challenge. Challenging patents that are believed to be invalid vindicates "the important public interest in permitting full and free competition in the use of ideas which are in reality a part of the public domain." 155 Because of the risk of free riding - that those who did not incur the cost of challenging the patent can now practice the invention if the patent is invalidated-validity challenges may be undersupplied, requiring even more of an incentive to bring such challenges. ${ }^{156}$

One can see the need for such an incentive in another context, that of pharmaceutical litigation under the Hatch-Waxman Act. ${ }^{157}$ The statutory structure of Hatch-Waxman is designed to encourage such challenges. Hatch-Waxman created a complex regulatory regime designed to balance the interests of pharmaceutical patent owners and generic manufacturers. An important design feature of this structure is the 180-day exclusivity period that is provided to the first generic company to challenge a pharmaceutical company's patent. The first generic company to successfully challenge the patent-either by showing no infringement or patent invalidity or unenforceability-receives 180 exclusive days where only the challenger and the patent

153 Lear, Inc. v. Adkins, 395 U.S. 653, 656 (1969) (citing Compco Corp. v. Day-Brite Lighting, Inc., 376 U.S. 234 (1964); Sears, Roebuck \& Co. v. Stiffel Co., 376 U.S. 225 (1964)).

154 See generally Joseph Scott Miller, Building a Better Bounty: Litigation-Stage Rewards for Defeating Patents, 19 Berkeley Tech. L.J. 667, 677-95 (2004) (discussing an accused infringer's incentives to challenge a patent's validity versus accepting an attractive settlement).

155 Lear, 395 U.S. at 670.

156 See Miller, supra note 154, at 688-95 (discussing undersupply of validity challenges).

157 See generally Hon. Kimberly A. Moore, Timothy R. Holbrook \& John F. Murphy, Patent Litigation and Strategy (4th ed. 2013) (discussing structure and purpose of Hatch-Waxman Act). 
holder will be on the market. ${ }^{158}$ The exclusivity period creates an incentive for generic companies to challenge patents promptly, particularly on the validity side. ${ }^{159}$ Such an incentive is also necessary: if a generic company invalidates the patent, then other generic companies can quickly enter the market (if they have FDA approval). Why would a generic company incur the substantial cost of patent litigation only to allow other competitors to enter the market without incurring that expense?

The criticism often levied against the PTO is that it is too lax in policing patent applications, allowing far too many patent claims to issue that do not actually satisfy the patentability requirements. ${ }^{160}$ There appears to be a significant number of invalid patents issued by the PTO, suggesting a need to preserve the incentive to challenge patents in court. Data show that many litigated patents are in fact invalidated. A recent study of all patent cases filed in 2008-2009 showed that validity challenges were successful $42.4 \%$ of the time. ${ }^{161}$ Such an invalidity rate is particularly striking given that patents are presumed valid, requiring accused infringers to prove invalidity under the heightened clear and convincing standard. ${ }^{162}$

Having invalid patents lurking around markets is not harmless. Invalid patents can have significant impacts on competition, even if they are not enforced. ${ }^{163}$ The Federal Trade Commission has noted that "[p]oor patent quality and legal standards and procedures that inadvertently may have anticompetitive effects can cause unwarranted market power and can unjustifiably increase costs. Such effects can hamper competition that otherwise would stimulate innovation." 164 As such, there are a considerable number of invalid patents lurking in the marketplace, with potential harmful consequences for competition. Lear and its progeny support a policy of incentivizing challenges to those patents.

Permitting liability even when a potential inducer has a good faith belief in invalidity undermines this interest in challenging patents because it risks chilling appropriate market entry and the potential attendant patent challenge. With a defense based on a good faith belief that the patent is invalid, the company can enter the market with a reduced sense of risk that their behavior will trigger liability. If they have such a good faith belief, then market entry is desirable. The potential exposure to liability, however, may deter

158 21 U.S.C. $\$ 355$ (j) (5) (B) (iv) (I) (2012).

159 See Moore, Holbrook \& Murphy, supra note 157, at 467.

160 For an argument as to why such a permissive result is rational, see Mark A. Lemley, Rational Ignorance at the Patent Office, 95 Nw. U. L. Rev. 1495 (2001).

161 John R. Allison et al., Understanding the Realities of Modern Patent Litigation, 92 Tex. L. REv. 1769, 1787 fig. 4 (2014).

162 Microsoft Corp. v. i4i Ltd. P'ship, 131 S. Ct. 2238, 2242 (2011).

163 See generally Christopher R. Leslie, The Anticompetitive Effects of Unenforced Invalid Patents, 91 Minn. L. Rev. 101, 113-39 (2006) (discussing the relationship between patent law and antitrust).

164 Fed. Trade Comm'n, To Promote Innovation: The Proper Balance of Competition and Patent Law and Policy 5 (2003). 
such behavior even though, at the time, they believe their activity would not trigger liability.

Of course, ultimately, that accused inducer's belief must have been wrong for this issue to arise in litigation-a court has found the patent infringed and not invalid. So, the infringer "may believe the patent [is] invalid," but, "[o]f necessity, litigated inducement decisions are all cases in which those beliefs turn out to be wrong; there can be no inducement if there is no direct infringement of a valid patent." 165

The Court recognized correctly that "it is often more difficult to determine whether a patent is valid than whether it has been infringed." 166 An assessment of infringement involves considering the device made by the potential infringer and comparing it to the claims in a potentially infringed patent. Generally, all of the information required for such an assessment is within the possession of the potential inducer. In contrast, a validity opinion requires performance of a potentially costly prior art search and then a comparison of the prior art to the claims, a more costly and potentially more complicated proposition. Parties, therefore, rationally may want to obtain only an infringement assessment and forego one for validity ex ante. ${ }^{167}$

But such concerns, contrary to the Supreme Court's suggestion, do not justify precluding the use of such a belief if a party has undergone such expense and effort. It also ignores the relationship that may exist among claim construction, infringement, and invalidity. A party evaluating the construction of a patent may generate both non-infringement and invalidity arguments depending on a broad or narrow construction. Moreover, given the public benefit that flows from an invalidity determination, one would expect the Court to incentivize validity challenges, not create an incentive against seeking validity opinion. While the Court lauds this dynamic as supporting its conclusion, it is actually a negative consequence of the Court's holding.

Nevertheless, from the ex ante perspective, if a good faith belief in the patent's invalidity would negate liability for induced infringement, parties holding such a belief are more likely to enter the market. ${ }^{168}$ Such behavior is pro-competitive and could bring questionable patents before the courts. ${ }^{169}$ Conversely, if a party can be liable for inducement even if they believe the patent is invalid, they may decline to enter the market or engage in expensive

165 Lemley, supra note 30, at 243.

166 Commil USA, LLC v. Cisco Sys., Inc., 135 S. Ct. 1920, 1930 (2015) (quoting Cardinal Chem. Co. v. Morton Int'l Inc., 508 U.S. 83, 99 (1993)).

167 My thanks to Jason Rantanen for bringing this argument to my attention and making it more salient in my mind.

168 Holbrook, Intent Element, supra note 5, at 408 ("Truly culpable parties are those that intend to induce infringement and not those who simply intend to induce the acts that constitute infringement. To hold otherwise would penalize a 'good' actor who holds a belief that the others are not directly infringing. Such behavior is pro-competitive-it encourages parties to enter the market if they have such a belief.").

169 Id. ("Allowing these parties to enter the market may create incentives to challenge otherwise potentially invalid patents."). 
design-around activity if they are risk averse. ${ }^{170}$ A conclusion that a party may still be liable for inducing infringement if she holds a good faith belief that the patent is invalid undermines the interest in encouraging patent challenges.

The Supreme Court nevertheless ignored these potential consequences and, as a result, has retreated from the policy of Lear and its progeny. Such retreat became crystal clear when the Court embraced the use of alternative mechanisms to challenge arguably invalid patents, such as a declaratory judgment action, inter partes review, ex parte reexamination, or the affirmative defense of invalidity. ${ }^{171}$

This litany of alternative mechanisms of challenging the patent ignores the initial threshold issue of whether a company should enter into an enterprise or not. The Court now makes it incumbent on a potential competitor-again one who believes the patent is invalid-to incur additional cost to clear the patent away, as opposed to simply entering the market and forcing the patent owners hand. None of these options are specific to inducers, either. They apply to anyone potentially liable for infringement.

Moreover, the options may not be as readily viable as the Court makes them out to be. A competitor who has not yet entered the market would have difficulty - if not face impossibility-in satisfying the conditions for a declaratory judgment action. There may not yet be a case or controversy that would allow the potential inducer to get into court. The party may choose simply not to enter the market rather than enter and risk potential liability, even if she believes the patent is invalid.

While a party could seek review through inter partes review or ex parte reexamination, those processes are not cost-free. They also may not eliminate the patent or clarify all validity issues, particularly given the differences used by the PTO in claim construction ${ }^{172}$ and the availability of claim amendments during these procedures. ${ }^{173}$ Inter partes review and ex parte

170 See Michael J. Burstein, Rethinking Standing in Patent Challenges, 83 Geo. Wash. L. REv. 498, 513-14 (2015) ("In some cases, a firm will find it not worth the risk to undertake activity that requires investment that can then be held up in the face of adverse intellectual property. This is especially so because many startups and technology entrepreneurs are rationally risk averse.”).

171 Commil, 135 S. Ct. at 1929.

172 The PTO affords claims their broadest reasonable interpretation, in contrast with the approach used in litigation where the courts construe the claims in accordance with the claims in the patent, the patent specification, the record during the patent's prosecution at the PTO, and any relevant evidence extrinsic to the public record. See generally Dawn-Marie Bey \& Christopher A. Cotropia, The Unreasonableness of the Patent Office's "Broadest Reasonable Interpretation” Standard, 37 AIPLA Q. J. 285 (2009).

17335 U.S.C. $\$ 305$ (2012) (ex parte reexamination); id. $\$ 316$ (d) (inter partes review); $i d$. $326(\mathrm{~d})$ (post grant review). Critics have noted the PTO's unwillingness so far to allow amendments in inter partes review proceedings, though one such motion has finally been successful. See John R. Schroeder, PTAB Finally Grants a Motion to Amend in Inter Partes Review, Senniger Powers (June 3, 2014), http://www.senniger.com/article-details.aspx?ar ticle $=3667 \&$ articlegroup $=\#$ sthash.OC4xNVkj.dpuf. 
reexamination are also limited to validity challenges based on printed publications and patents. ${ }^{174}$ While competitors are more likely to have these types of prior art, given their public nature, a competitor who would like to challenge the patent on the basis of a public use, on-sale activity, ${ }^{175}$ or inadequate disclosure cannot do so. A party can challenge a patent on any basis in post-grant review proceedings (PGR) and in the interim covered business method program $(\mathrm{CBM}){ }^{176}$ Post-grant review challenges can only be brought within nine months of the patent's issuance, creating significant time constraints on a potential challenger. ${ }^{177}$ As for CBM challenges, they are limited only to patents on methods of doing business, limiting their usefulness to broader types of inventions. ${ }^{178}$ A CBM proceeding also can only be instituted once a party has been accused of, or sued for, infringement. ${ }^{179}$ Thus, these various procedures are not the panacea that the Supreme Court painted them to be. If the challenge is unsuccessful, a potential inducer may yet have to face a validity challenge in court.

As for raising a defense in litigation, the accused infringer of course must have raised the issue but was unsuccessful. If it was successful, we wouldn't be addressing the issue of a good faith belief in invalidity. Regardless, all of this ignores the ex ante incentives that a potential competitor with

17435 U.S.C. $\$ \S 301$ (a) (1); id. $\$ 302$ (noting that reexamination is limited to prior art of $\$ 301$, which lists only printed publications and patents); $i d$. $\$ 311$ (b) (noting that inter partes review is only available "on the basis of prior art consisting of patents or printed publications.").

175 The 1952 Patent Act precluded a patent if the invention was on sale or in public use more than a year before the filing date of the relevant patent application. Id. $§ 102(\mathrm{~b})$. The America Invents Act, which changed the United States from a first-to-invent system to a first-inventor-to-file system, also precludes a patent if the invention was in public use or on sale. Id. $\S 102(\mathrm{a})$.

$176 I d . \$ 321$ (b) (noting that a PGR can be brought on any ground "under paragraph (2) or (3) of section 282(b) (relating to invalidity of the patent or any claim)"); America Invents Act, Pub. L. 112-29, § 18(a)(1), 125 Stat. 284, 329 (2011) (noting that CBM "shall employ the standards and procedures of [ ] a post-grant review").

17735 U.S.C. $\$ 321$ (c). These proceedings can also only be used to challenge patents prosecuted under the AIA, although this is a temporary concern. See id. § 2(f)(2)(A) (noting that the provision applies "only to patents described in section $3(n)(1)$," the provision defining the new first-inventor-to-file regime).

178 Section $18(\mathrm{a})(1)(\mathrm{E})$ of the AIA notes that " $[\mathrm{t}]$ he Director may institute a transitional proceeding only for a patent that is a covered business method patent." AIA $\S 18(a)(1)(E)$. Section 18(d)(1) defines "covered business method patent" as "a patent that claims a method or corresponding apparatus for performing data processing or other operations used in the practice, administration, or management of a financial product or service, except that the term does not include patents for technological inventions." Id. $\S 18(d)(1)$. The Federal Circuit has allowed challenges on appeal to whether a patent is properly considered a covered business method patent. See Versata Dev. Grp., Inc. v. SAP Am., Inc., 793 F.3d 1306, 1319-20 (Fed. Cir. 2015).

179 AIA $\$ 18(\mathrm{a})(1)(\mathrm{B})$ ("A person may not file a petition for a transitional proceeding with respect to a covered business method patent unless the person or the person's real party in interest or privy has been sued for infringement of the patent or has been charged with infringement under that patent.”). 
knowledge of the patent faces. One would hope a competitor who doubts a patent's validity would err on entering the market. Instead, the Supreme Court chills such behavior, or at least makes it more costly by making it incumbent on the competitor to affirmatively challenge the patent, before the patent holder potentially has expressed any interest in enforcing the patent at all.

In sum, the Supreme Court's decision in Commil represents a retreat from the policy interest advanced in Lear and its progeny to encourage patent validity challenges. The Court suggested few parties may have the economic incentive to bring such challenges, which makes sense given that invalidity determinations act as a public good and thus may be undersupplied. The Court in Commil, however, undermines the incentive that potential competitors-inducers-will have to bring such challenges. These parties may enter the market if they believe that they do not infringe the patent. If their belief is limited to invalidity, however, such parties may choose not to enter the market or may otherwise design around the patent, incurring potentially wasteful costs in so doing. From this perspective, Commil is step in the wrong direction.

\section{Unanswered Questions and Missed Opportunities}

The Court's step away from Lear in its Commil decision is significant, but equally important are the questions left unanswered by the Court that will need to be addressed by the district courts and eventually the Federal Circuit. First, a patent may be valid yet unenforceable for some reason, such as when the applicant commits inequitable conduct at the PTO or when the patent owner has misused the patent. The Court's bifurcation of infringement and invalidity therefore is underinclusive as to the range of potential outcomes of patent litigation.

Second, and more importantly, the Supreme Court failed to explain the temporal aspect of the inducement mental state. In particular, the Court implicitly retains the rule that a good faith belief that the induced acts are not infringing should serve as a defense. Nevertheless, the issue of a good faith belief that the induced acts do not infringe creates timing issues. Once the accused inducer has been proven wrong-that the acts are infringing-then there is no reason to immunize the inducer from prospective relief. The Supreme Court failed to recognize this temporal dynamic, as has the Federal Circuit. The Federal Circuit should adopt a rule that such a good faith belief only acts to immunize the inducer from past damages and not from prospective relief, such as an injunction or ongoing damages. This Section unpacks these oversights by the Supreme Court and offers potential answers to them.

\section{A. What About a Good Faith Belief in Unenforceability?}

The decision in Commil is specific to a good faith belief in the patent's invalidity, and it implicitly confirms that such a belief of non-infringement 
will negate the required intent. There are other reasons, however, that a potential inducer may believe that it will not be liable for infringement.

For example, a patent may be rendered unenforceable under a number of equitable doctrines. If the patent applicant violated her duty of candor at the PTO, then the patent may be unenforceable under the doctrine of inequitable conduct. ${ }^{180}$ If the patentee unduly delays the issuance of the patent, then it may be unenforceable under the doctrine of prosecution laches. ${ }^{181}$ After patent issuance, a patent may be unenforceable if the owner has attempted to leverage the patent in anticompetitive ways under the doctrine of patent misuse. ${ }^{182}$ Patents may also be unenforceable as a result of other equitable defenses, such as laches or equitable estoppel. ${ }^{183}$ The question remains as to whether a good faith belief in any of these or other defenses should negate the required mental state for active inducement.

Although this is technically an open question, the courts likely will answer it in the negative readily, if and when the issue is presented. The

180 See Therasense, Inc. v. Becton, Dickinson and Co., 649 F.3d 1276, 1310-1311 (Fed. Cir. 2011) (en banc). To be clear, inequitable conduct may not be a frequent basis for an ex ante belief regarding enforceability of the patent. Assessing inequitable conduct prior to litigation may be difficult because the determination rests on the mental state of the patent applicant-did the applicant have the "specific intent to deceive the PTO." See id. at 1290. Such an assessment would be difficult, if not impossible, prior to litigation because a party likely would need to depose the applicant and her attorneys. See Jason Rantanen \& Lee Petherbridge, Toward a System of Invention Registration: The Leahy-Smith America Invents Act, 110 Mich. L. Rev. First Impressions 24, 25 (2011) ("As uncovering most forms of inequitable conduct requires a searching analysis of the candor of the applicant's behavior during a secret ex parte process, it seems improbable that patent challengers will learn of the relevant conduct before discovery.").

181 See, e.g., Symbol Techs., Inc. v. Lemelson Med., Ed. \& Research Found., LP, 422 F.3d 1378, 1384-86 (Fed. Cir. 2005).

182 See Princo Corp. v. Int'l Trade Comm'n, 616 F.3d 1318, 1328 (Fed. Cir. 2010) (en banc).

183 SCA Hygiene Prods. Aktiebolag SCA Pers. Care, Inc. v. First Quality Baby Prods., LLC, 807 F.3d 1311, 1315 (Fed. Cir. 2015) (en banc); A.C. Aukerman Co. v. R.L. Chaides Const. Co., 960 F.2d 1020, 1028 (Fed. Cir. 1992) (en banc). In SCA Hygiene, in a 6-5 vote, the en banc Federal Circuit retained laches as a defense to past damages in light of Petrella v. Metro-Goldwyn-Mayer, Inc., 134 S. Ct. 1962 (2014), but altered its impact on prospective relief:

We conclude that Congress codified a laches defense in 35 U.S.C. $§ 282$ (b) (1) that may bar legal remedies ....

Nevertheless, we must adjust the laches defense in one respect to harmonize it with Petrella and other Supreme Court precedent. We emphasize that equitable principles apply whenever an accused infringer seeks to use laches to bar ongoing relief. Specifically, as to injunctions, considerations of laches fit naturally within the eBay framework. In contrast, Menendez v. Holt, 128 U.S. 514 (1888), and Petrella counsel that laches will only foreclose an ongoing royalty in extraordinary circumstances.

SCA Hygiene, 807 F.3d at 1315. In contrast to inequitable conduct, laches and equitable estoppel involve assessments of actions by the patentee that are well within the grasp of the accused inducer. As such, ex ante assessments of these defenses are far more likely. 
reasoning the Court used to distinguish invalidity and infringement applies with even greater force in the context of these other defenses. While unenforceability is listed as a defense in the same statutory provision as noninfringement, unenforceability is still listed separately from non-infringement within that provision. ${ }^{184}$ Moreover, these defenses are not linked together the way infringement and invalidity are through claim construction. Most of these defenses rest on acts by the patentee and not based on the content of the patent itself. ${ }^{185}$

As such, the answer to this open question seems clear: a good faith belief in these other defenses will not negate the scienter requirement for active inducement. Only a good faith belief in non-infringement will be available as a defense to active inducement of infringement.

\section{B. A Good Faith Belief of Non-Infringement Should Only Immunize a Party from Past Damages and Not from Prospective Relief}

Because a good faith belief in non-infringement remains a viable way to negate the scienter requirement, then another issue also arises: What is the impact of that negation? The only reason the issue of the inducer's good faith belief would arise in litigation is because the inducer was wrong-at trial she was unable to prove that the induced acts were non-infringing. If she were correct, then there would simply be no liability for lack of a direct infringer. ${ }^{186}$ The unanswered question then is the extent to which the good faith belief in non-infringement should serve as a defense.

Consideration of the purposes of active inducement lead to the conclusion that a good faith belief of non-infringement should act as a defense only to past damages. Once a court has rejected the accused inducer's noninfringement arguments, there is no longer a possibility that the inducer has a good faith basis for believing that the patent is not infringed. ${ }^{187}$ Unless the infringer alters her conduct after a final determination of infringement, any ongoing behavior necessarily will be infringing. Because the accused infringer's belief regarding infringement has now been disabused, the inducer should be liable for any ongoing conduct. The belief should not act as an absolute defense to all relief, past and future.

Consequently, the inducer should be subject to a permanent injunction, if warranted, ${ }^{188}$ or liable for future damages, such as ongoing royalties. ${ }^{189}$

184 See 35 U.S.C. $\$ 282$ (b) (1) (2012) (noting as defenses “[n] oninfringement, absence of liability for infringement or unenforceability.”). Invalidity defenses are listed in $\S \S 282(\mathrm{~b})(2)$ and (3).

185 See Margo A. Bagley, The New Invention Creation Activity Boundary in Patent Law, 51 WM. \& MARY L. Rev. 577, 580 (2009).

186 Limelight Networks, Inc. v. Akamai Techs., Inc., 134 S. Ct. 2111, 2117 (2014) (holding that, for inducement, there must be a direct infringer).

187 The Court would also have to find the patent not invalid for liability.

188 The Court rejected the Federal Circuit's near per se rule of granting permanent injunctions if a party is found to infringe a valid patent. eBay Inc. v. MercExchange, L.L.C., 547 U.S. 388, 393-94 (2006). If a party is not entitled to the four-factor test articu- 
Once the patent is found not invalid and infringed, the belief of the inducer no longer matters. Any future infringing conduct should be stopped through injunctive relief or should be subject to an ongoing royalty.

While this temporal aspect seems clear, the courts have yet to hold expressly that a good faith belief in non-infringement is only a defense to past damages. This question remains an open one. In one recent non-precedential decision, Bose Corp. v. SDI Technologies, Inc., the Federal Circuit explored the temporal aspect of such a good faith belief but did not specifically hold that it failed to negate injunctive relief or ongoing damages. ${ }^{190} \mathrm{In}$ Bose, the appellant argued that the district court erred because its grant of summary judgment inappropriately "insulated SDI from potential post-verdict liability."191 The Federal Circuit agreed, noting that "[a] jury could, at trial, find the patent not invalid and infringed." 192 As a result, the court noted that "SDI's opinion of counsel would not shield it from post-verdict liability because SDI could not credibly argue that it maintained its good faith belief of invalidity following a verdict to the contrary. The summary judgment improperly absolved SDI of potential post-verdict liability." 193 The court remanded, however, because "[a] material dispute thus remain[ed] on the issue of whether SDI relied in good faith on its opinion of counsel." 194

Bose, of course, is no longer good law in light of Commil's rejection of the good faith belief regarding the patent's validity. Also, it is non-precedential, and the discussion of post-verdict liability is technically dicta. As a result, although courts have alluded to this temporal aspect of induced infringement, no court has expressly held that inducers should be subject to prospective relief, regardless of their pre-suit good faith belief in non-infringement.

Under the proposal offered here, the good faith belief in invalidity or non-infringement would function similarly to the way the defense of laches operated in patent law until recently. Laches is used as a defense when the accused infringer has been materially prejudiced by the patentee's unreasonable delay in bringing suit. ${ }^{195}$ Under Federal Circuit law, laches primarily

lated for a permanent injunction, it may still subject to paying an ongoing royalty. See, e.g., Paice LLC v. Toyota Motor Corp., 504 F.3d 1293, 1314 (Fed. Cir. 2007) ("Under some circumstances, awarding an ongoing royalty for patent infringement in lieu of an injunction may be appropriate.").

189 See Holbrook, Intent Element, supra note 5, at 405-07; see also Rantanen, supra note 38 , at 1603 n.162 ("[W]ith respect to future infringement, arguably neither contributory infringement nor inducement requires the demonstration of fault . . . In short, when litigating over future infringement, it should not be necessary to establish fault with respect to whether or not the third party conduct infringes.").

190 Bose Corp. v. SDI Techs., Inc., 558 Fed. App’x 1012 (Fed. Cir. 2014).

191 Id. at 1023.

$192 I d$.

$193 I d$. (emphasis added).

194 Id. at 1024.

195 SCA Hygiene Prods. Aktiebolag SCA Pers. Care, Inc. v. First Quality Baby Products, LLC, 807 F.3d 1311, 1315 (Fed. Cir. 2015) (en banc) ("We conclude that Congress codified a laches defense in 35 U.S.C. $\$ 282(\mathrm{~b})(1)$ that may bar legal remedies.”); A.C. 
acts as a defense to past damages. ${ }^{196}$ The good faith belief would operate similarly here, negating only past damages and not prospective relief.

The Supreme Court's decision in Commil failed to address this temporal dynamic, leaving the question open as to an accused inducer's good faith belief of non-infringement. The Court failed to appreciate how exposure to prospective relief helps mitigate some potential negative aspects of permitting good faith belief (be it non-infringement or the patent's invalidity) could create laudable effects beyond those addressed above.

Opponents of the good faith belief defense-be it invalidity or noninfringement-have expressed the concern that parties could easily obtain "rubber stamp" opinion letters. A party will simply hire an attorney who will opine, post-Commil, that there is no infringement, allowing the party to escape liability for inducement. ${ }^{197}$ One commentator has compared these opinion letters to consumer warning labels placed on products, which are viewed purely as a formality. ${ }^{198}$

These concerns are considerably mitigated, however, if a potential inducer is still exposed to prospective relief. ${ }^{199}$ Exposure to prospective relief would cabin an attorney's discretion in providing her opinion.

The possibility of a permanent injunction would act as a check on the attorney being overly optimistic about the likelihood of defeating an infringement suit. The client is relying on the opinion to plan its business operations and would want an honest assessment of the risk that they may have to shut operations down or alter them to avoid infringement. ${ }^{200}$

Aukerman Co. v. R.L. Chaides Constr. Co., 960 F.2d 1020, 1028-29 (Fed. Cir. 1992) (en banc) ("[L]aches may be defined as the neglect or delay in bringing suit to remedy an alleged wrong, which taken together with lapse of time and other circumstances, causes prejudice to the adverse party and operates as an equitable bar.”).

196 Aukerman, 960 F.2d at 1028 ("Where the defense of laches is established, the patentee's claim for damages prior to suit may be barred.”). The Federal Circuit maintained laches as a defense to past damages in SCA Hygiene but rejected Aukerman's suggestion that laches played no role with respect to ongoing relief. SCA Hygiene, 807 F.3d at 1332 ("Laches, an equitable defense, belongs in [the $e B a y$ ] calculus. We, accordingly, reject Aukerman's bright line rule regarding the interplay between laches and injunctive relief."). The court did conclude, however, that "absent egregious circumstances, when injunctive relief is inappropriate, the patentee remains entitled to an ongoing royalty." Id.

197 See, e.g., Brief for Intellectual Property Owners Ass'n as Amici Curiae Supporting Petitioner at 2, Commil USA, LLC v. Cisco Sys., Inc., 135 S. Ct. 1920 (2015) (No. 13-896) ("The end result is that virtually all potential infringers can easily absolve themselves of liability for inducing infringement of a valid patent for the price of an opinion letter from counsel.").

198 See Rader, supra note 30, at 332.

199 Minimally, this concern rests entirely on the assumption that attorneys would risk committing professional misconduct by rubber-stamping a letter that provides a legally inaccurate opinion. It is illogical to assume that an attorney would knowingly jeopardize her standing in the profession over an opinion letter.

200 Holbrook, Intent Element, supra note 5, at 410-11. 
That their clients may be exposed to future liability and injunctive relief should act as a check on any intuition that they should simply issue "rubber stamp" opinion letters.

Determining when the accused infringer has lost, and thus when damages begin to accrue, may create some uncertainty in litigation. But courts routinely deal with such grey areas. Complexities of litigation and damages calculations should not drive substantive patent law decisions. Lawyers should be able to sort out whatever point in time past damages end and future relief begins. Indeed, such complexities could arise in any case where injunctive relief comes into play. The Federal Circuit's general approach to laches belies the argument that such an approach is unworkable. Courts are well-equipped to make the appropriate determinations that take into consideration the rights of a patent holder on a case-by-case basis.

\section{Conclusion}

The Supreme Court's reworking of active inducement of infringement has been significant, yet overlooked. The Court, contrary to many of its other holdings, has generally been favorable to patent holders in the way it has interpreted $\S 271(\mathrm{~b})$, allowing liability in the absence of actual knowledge of the particular patent at issue and limiting "good faith" defenses solely to a good faith belief that the induced acts do not infringe. Nevertheless, these changes mark a stark departure from Lear's stated interest in generating challenges to patents. The Court, perhaps inadvertently, has retreated from this position, depending on a litany of pragmatic arguments that ultimately are unpersuasive.

The Supreme Court and Federal Circuit have also missed the important temporal dynamic that surrounds the good faith belief defense (now only of non-infringement): that belief only becomes relevant if the accused inducer was wrong. As such, from that point forward, no such belief can be in good faith, and it should not continue to shield the inducer from liability. A good faith belief in non-infringement should only act as a defense to past damages. An inducer should otherwise be subject to injunctive relief or, if appropriate, ongoing damages. 